\title{
Spatial proton exchange membrane fuel cell performance under bromomethane poisoning
}

\author{
Tatyana V. Reshetenko ${ }^{* a}$, KaterynaArtyushkova ${ }^{\mathrm{b}}$, Jean St-Pierre ${ }^{\mathrm{a}}$ \\ ${ }^{a}$ Hawaii Natural Energy Institute, University of Hawaii, Honolulu, HI 96822 \\ ${ }^{\mathrm{b}}$ Center for Microengineered Materials, \\ University of New Mexico, Albuquerque, NM 87131
}

\begin{abstract}
The poisoning effects of5 $\mathrm{ppm} \mathrm{CH}_{3} \mathrm{Br}$ in theair on thespatial performance of aproton exchange membrane fuel cell (PEMFC)were studied using a segmented cell system. The presence of $\mathrm{CH}_{3}$ Brcaused performance loss from 0.650 to $0.335 \mathrm{~V}$ at $1 \mathrm{~A} \mathrm{~cm}^{-2}$ accompanied by local current density redistribution. The observed behavior was explained bypossible bromomethane hydrolysis with the formation of $\mathrm{Br}^{-}$. Bromide and bromomethane negatively affected the oxygen reduction efficiencyovera wide range of potentials because oftheir adsorption on $\mathrm{Pt}$, which was confirmed by XPS. Moreover, the PEMFC exposure to $\mathrm{CH}_{3} \mathrm{Br}$ led toa decrease in the anode and cathode electrochemical surface area $(\sim 52-57 \%)$ due to the growth of Pt particles through agglomeration and Ostwald ripening. The PEMFC did not restore its performance after stopping bromomethane introduction to theair stream. However, the $\mathrm{H}_{2} / \mathrm{N}_{2}$ purge of the anode/cathode and $\mathrm{CV}$ scans almost completely recovered the cell performance. The observed final loss of $\sim 50 \mathrm{mV}$ was due to an increased activation overpotential. PEMFC exposure to $\mathrm{CH}_{3} \mathrm{Br}$ should be limited to concentrations much less than 5 ppm due to serious performance loss and lack of self-recovery.
\end{abstract}

Key words: PEMFC; Pt cathode; Bromomethane; Airborne contaminant; Segmented cell

\section{Introduction}

The successful commercial deployment of proton exchange membrane fuel cells (PEMFCs) requires their reliability, durability and high performance under different operating and environmental conditions. Air is the most practical and economic oxidant for automotive and stationary fuel cell applications, and it is an important consideration because any airborne impurities can compromise PEMFC performance [1-4]. Moreover, the quality of the air is a critical factor for fuel cells where air filtration cannot be implemented due to weight and/or volume restrictions. Previous studies of urban inorganic air contaminants showed that sulfur-containing compounds $\left(\mathrm{SO}_{2}, \mathrm{H}_{2} \mathrm{~S}\right.$, COS $)$ caused the most severeand irreversible impacts on PEMFC [1, 5-9], while the effects of nitrogen-containing pollutants $\left(\mathrm{NO}_{2}, \mathrm{NH}_{3}\right)$ resulted in moderate impacts $[1,6,7,10,11]$. The operation of fuel cells in the marine environment can be significantly damaged by $\mathrm{NaCl}$, which is a major component of seawater and air mists [12-17]. PEMFC exposure to some common organic air contaminants usually led to a reversible performance loss $[1,2,18,19]$, whereas hazardous chemical warfare agents such as sarin, 
sulfur mustard, cyanogen chloride, and hydrogen cyanide resulted in serious irreversible fuel cell deterioration [1].

PEMFC contamination effects can be separated into three main categories depending on the affected membrane-electrode assembly (MEA) components: (1) kinetic, (2) ohmic and (3) mass transfer effects [4]. Chemisorption of the contaminant on the Pt surface decreasesthe available electrochemical area (ECA) and affects the oxygen reduction reaction (ORR) kinetics and elementary steps, shifting the mechanism from a 4-electron to a 2-electron reaction. Pollutants and/or their derivatives mayinteract with an ionomer in the membrane and catalyst layers, reducing the proton conductivity and increasing the ohmic losses. In addition, the adsorption of airborne contaminants can block the Pt surface and modify the hydrophobicity and structure of the MEA components, which alters the mass transfer properties. In reality, the contamination impact is a combination of all of these processes and depends on the chemical nature of the air impurities.

Recently, several possible organic air pollutants from the Environmental Protection Act list were selected for detailed studies of their effects on PEMFC [20]. The contaminants belong to different classes of organic compounds: alkenes $\left(\mathrm{C}_{3} \mathrm{H}_{6}\right)$, alkynes $\left(\mathrm{C}_{2} \mathrm{H}_{2}\right)$, arenes $\left(\mathrm{C}_{6} \mathrm{H}_{6}, \mathrm{C}_{10} \mathrm{H}_{8}\right)$, alcohols (i$\left.\mathrm{C}_{3} \mathrm{H}_{7} \mathrm{OH}\right)$, nitriles $\left(\mathrm{CH}_{3} \mathrm{CN}\right)$, esters $\left(\mathrm{CH}_{2}=\mathrm{C}\left(\mathrm{CH}_{3}\right) \mathrm{COOCH}_{3}\right)$ and alkyl halides $\left(\mathrm{CH}_{3} \mathrm{Br}\right)$. The selected compounds are widely used as chemical reagents, solvents, welding fuels, and pesticides. Moreover, all of them caused an adverse impact on the ORR and PEMFC [20-23].

Bromomethane was included in the study because it is a volatile, toxic, ozone-depleting substance and has both natural and anthropogenic atmospheric emissionssources. The anthropogenic sources include biomass burning, vehicle exhausts, and agricultural usage. The application of $\mathrm{CH}_{3} \mathrm{Br}$ as a fumigant to control pests in agriculture and shipping has been reduced in the USA since 2005 according to the amendment to the Montreal protocol (UNEP, 1995). However, bromomethane has a major natural emission source from oceans, which makes it a relevant contaminant for detailed studies [24-28]. Atmospheric concentrations of $\mathrm{CH}_{3} \mathrm{Br}$ over the oceans and in rural areas are typically less than $25 \mathrm{ppt}$, while in urban and industrial areas it may be as high as $1.2 \mathrm{ppb}[25,28]$. The chemistry of atmospheric $\mathrm{CH}_{3} \mathrm{Br}$ was intensively studied due to its ozone-destructive capabilities. The main degradation pathway for bromomethane is a reaction with photochemically generated hydroxyl radicals, which leads to an atmospheric lifetime between 1.6 and 2.0 years [24, 25,28]. Bromomethane slowly hydrolyses in water, yielding methanol, bromide, and a proton. Its hydrolytic half-life ranges between 20 and 38 days depending on the temperature and $\mathrm{pH}$ [28-30]. There are a few studies devoted to the adsorption of bromomethane on $\mathrm{Pt}$ [31-33], while there isa lack of studies on the electrochemical behavior of $\mathrm{CH}_{3} \mathrm{Br}$ in aqueous solutions. However,the adsorption of related species such as $\mathrm{Br}^{-}$on $\mathrm{Pt}$ and their impactson hydrogen oxidation and oxygen reduction were previously investigated and published [34- 46]. The application of the rotating ring-disk electrode (RRDE) method demonstrated that strongly adsorbed bromide suppresses the adsorption of oxygen and hydrogen, prevents the formation of the catalytic sites needed to break the bonds in the oxygen molecule and alters the ORR pathway through theintermediate production of $\mathrm{H}_{2} \mathrm{O}_{2}$ [34-43]. 
The evaluation of Pt electrocatalysts by RRDE cannot provide any predictable information about PEMFC performance and behavior in the presence of air pollutants due to different operating conditions (temperature and back pressure) and environments (gaseous vs. aqueous). In addition, single cell testing can allow researchers to measure only the average values of current, voltage, and impedance, while spatial characterization of fuel cell performance reveals unique and valuable results about local performance [47-51], water management [52-57], defect determination [5862],recirculation[63], start-up and starvation impact[64-67]. Previous successful applications of a segmented cell system for studying and understanding PEMFC performance exposed to air and fuel contaminants demonstrated the powerful and exceptional capabilities [22, 23, 68]. The current work is a continuation of our previously published results $[22,23]$ and presents detailed studies of long-term localized PEMFC performance under cathode poisoning by $5 \mathrm{ppm} \mathrm{CH}_{3} \mathrm{Br}$ and its comparison to a fuel cell operated without any impurities to understand the impacts of $\mathrm{CH}_{3} \mathrm{Br}$, improve the environmental adaptability, and establish the air quality requirements for PEMFC application. To accelerate the effects of the pollutant on fuel cells, the chosen concentration of bromomethane is higher than observed in average environmental conditions.

\section{Experimental}

The work was performed using a GRandalytics single fuel cell test station and a segmented cell system developed at the Hawaii Natural Energy Institute [56]. The segmented cell system was build based on previouswork [48, 49,69, 70] and allows simultaneous spatial electrochemical characterizations such as impedance spectroscopy (EIS), cyclic voltammetry (CV)and linear sweep voltammetry (LSV).A detailed description of the experimental setup is available in our previous publications [56].

Commercially available, non-segmented,Gore, $100 \mathrm{~cm}^{2}$ active area MEAs were used for contamination and blank tests. The anode and cathode consisted of $\mathrm{Pt} / \mathrm{C}$ catalyst layers with a loading of $0.4 \mathrm{mg}_{\mathrm{Pt}} \mathrm{cm}^{-2}$. The gas diffusion layer (GDL) was sourced from SGL (25 BC). A segmented GDLwas employed for the cathode, whereas a single GDL was used at the anode. The total cathode active area was $76 \mathrm{~cm}^{2}$ due to the cathode segmentation.

The anode/cathode testing conditions were $\mathrm{H}_{2}$ /air, $2 / 2$ stoichiometry, $100 / 50 \%$ relative humidity and $48.3 / 48.3 \mathrm{kPa}_{\mathrm{g}}$ backpressure. The cell was kept at $80^{\circ} \mathrm{C}$. Blank and contamination tests were performed at an overall current density of $1.0 \mathrm{~A} \mathrm{~cm}^{-2}$ (galvanostatic control). The dry air mixture containing 100 ppm $\mathrm{CH}_{3}$ Brwas introduced into a humidified air streamat aflow rate of $0.1251 \mathrm{~min}^{-1}$ resulting in a contaminant concentration of $5 \mathrm{ppm}$. The desired humidificationof the oxidant gaswas maintained by simultaneously increasing the humidifier temperature.

Performance andperformance losses (activation, ohmic and mass transfer)were determined by measuring polarization curves (VI curves) with $\mathrm{H}_{2} /$ air, $\mathrm{H}_{2} / \mathrm{He}+\mathrm{O}_{2}\left(21\right.$ vol.\%) and $\mathrm{H}_{2} / \mathrm{O}_{2}$ [56]. Spatial EIS were recorded at the same time as VI curves. The frequency was varied from $0.05 \mathrm{~Hz}$ to $10000 \mathrm{~Hz}$. The amplitude of the current perturbation was $2 \mathrm{~A}$, which corresponded to a voltage signalof $10 \mathrm{mV}$ or less. The ECA was determined by $\mathrm{CV}$ performed at $35^{\circ} \mathrm{C}$ with a scan rate of 
$20 \mathrm{mV} \mathrm{s}^{-1}$ using a Solartron SI 1287/electrochemical interface.

The MEA, anode, and cathode catalysts were studied by scanning electron microscopy (SEM), transmission electron microscopy (TEM) and X-ray photoelectron spectroscopy (XPS). A Kratos XPS ultra DLD spectrometer operating with an $\mathrm{Al} \mathrm{K \alpha}$ monochromatic source at $225 \mathrm{~W}$ was used to obtain high-resolution F 1s, C 1s, O 1s, Pt 4f and Br 3p spectra. SEM images were obtained with a Hitachi S4800 field emission microscope with an accelerating voltage of $5 \mathrm{kV}$. TEM studies of the catalysts were performed using a Hitachi HT-7700. The particle size distribution (PSD) for each sample was created from the TEM imagesand a random selection of 400-600 Pt particles.

\section{Results}

\subsection{A comparison of PEMFCsperformancesexposed to $5 \mathrm{ppm} \mathrm{CH}_{3} \mathrm{Br}$ and operated with pure air}

Fig. $1 \mathrm{a}, \mathrm{bz}$ ) presents the profiles of the segment voltages and current densities normalized to their initial values under exposure to $\mathrm{CH}_{3} \mathrm{Br}$ at $1.0 \mathrm{~A} \mathrm{~cm}^{-2}$. For the first $18 \mathrm{~h}$, the cell was operated with pure air resulting in a cell voltage of $0.650 \mathrm{~V}$. The initial current density distribution ranged from 0.85 to $1.15 \mathrm{~A} \mathrm{~cm}^{-2}$. The injection of $5 \mathrm{ppm}$ of $\mathrm{CH}_{3} \mathrm{Br}$ in the air did not result in immediate performance degradation. The voltage started gradually decreasing only after $9 \mathrm{~h}$ of exposure to bromomethane and reached a plateau of $0.335 \mathrm{~V}$. The delay in PEMFC response is likely connected to a chemical and/or electrochemical transformation of $\mathrm{CH}_{3} \mathrm{Br}$ and the further impact of its derivatives on the electrode catalysts. Thus, three well-definedstages were observed: 1) lack of any changes in the cell performance within 9 hours, 2) fast degradation from 0.650 to $0.440 \mathrm{~V}$ for $45 \mathrm{~h}$ of exposure ( $62 \mathrm{~h}$ of total operation) and 3) slow degradation (0.440-0.335 V). The PEMFC behavior under cathode poisoning by $\mathrm{CH}_{3} \mathrm{Br}$ was found to resemble fuel cell performance exposed to $\mathrm{HCl}$ and $\mathrm{NaCl}$ [12-17], which allowed us to assume similarities in the poisoning mechanisms of $\mathrm{Cl}^{-}$and bromomethane. As mentioned previously, $\mathrm{CH}_{3} \mathrm{Br}$ was expected to be slowly hydrolyzed in aqueous media with the formation of $\mathrm{CH}_{3} \mathrm{OH}, \mathrm{Br}^{-}$and $\mathrm{H}^{+}$[28-30]. Methanol can be further oxidized to $\mathrm{CO}_{2}$ and $\mathrm{H}_{2} \mathrm{O}$ at the fuel cell cathode by chemical or electrochemical pathways [71-73], which led us to suspect that $\mathrm{Br}^{-}$primarily accounts for performance degradation during the third stage because the process was slow.

The voltage loss was accompanied by noticeable current redistributions for these three regions. During the first stage, the current density distribution was not affected. At the second stage, the current densities of segment 1 and 6 slightly increased by 5\%, segments 2, 3, 5, 7, and 8 did not show significant changes, while current densities of segments 4,9 , and 10 decreased by $3-5 \%$. The third stage started when the voltage reached an inflection point at $0.440 \mathrm{~V}$. Inlet segments 1-5 increased

performance during the third stage while the performance of outlet segments 6-10 declined. At steady state, the inlet segments had greater performances than the outlet segments. The current density redistribution ranged from $+12 \%$ for segment 1 to $-19 \%$ for segment 9 due to the operation of the cell in agalvanostatic mode, which required an overall constant current. The cell and segments did not recover their performance after stopping the $\mathrm{CH}_{3} \mathrm{Br}$ poisoning for $70 \mathrm{~h}$, and the current distribution was still evolving. 

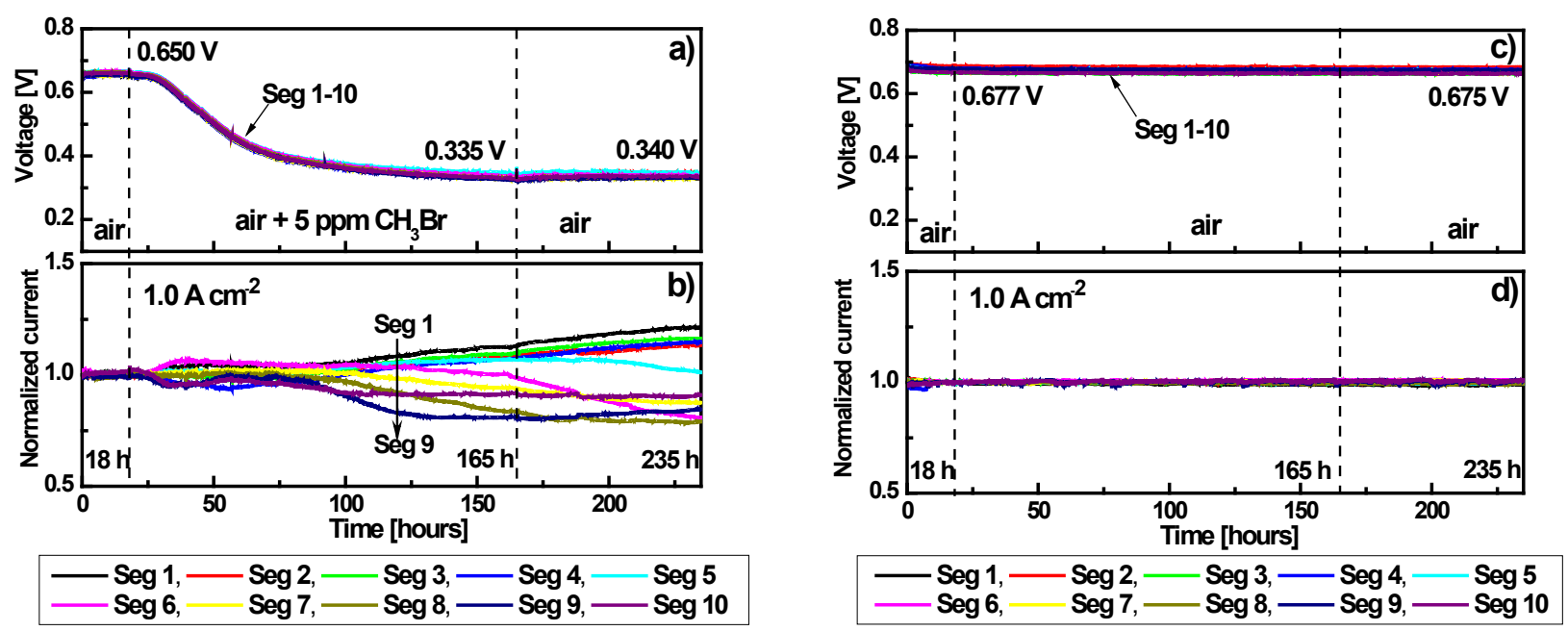

Fig. 1. Voltage (a) and normalized current densities (b) of individual segments of PEMFC exposed to 5 ppm $\mathrm{CH}_{3} \mathrm{Br}$; voltage (c) and normalized current densities (d)for PEMFC operated without $\mathrm{CH}_{3} \mathrm{Br}$. An overall current density is $1.0 \mathrm{~A} \mathrm{~cm}^{-2}$. Anode/cathode: $\mathrm{H}_{2} /$ air, $1.059 / 2.5221 \mathrm{~min}^{-1}, 100 / 50 \% \mathrm{RH}$, $48.3 / 48.3 \mathrm{kPa}_{\mathrm{g}}, 80^{\circ} \mathrm{C}$.

Localized voltages and normalized current densities of PEMFC operated without the $\mathrm{CH}_{3} \mathrm{Br}$ exposure are shown in Fig. $1 \mathrm{c}, \mathrm{d}$ ). The initial voltage was $0.677 \mathrm{~V}$, which is a little bit higher than in the case of $\mathrm{CH}_{3} \mathrm{Br}$ and might be explained by slight variations in the initial MEA properties. PEMFC performance within $235 \mathrm{~h}$ was very stable, and the degradation rate was $8.5 \cdot 10^{-6} \mathrm{~V} \mathrm{~h}^{-1}$. At the same time, no spatial current density redistributions were observed. A comparison of Figs. $1 \mathrm{~b}$ ) and $1 \mathrm{~d}$ ) clearly showed the effects of the air pollutant on local currents, demonstrating propagation of the contamination along the flow field. Bromomethane or products of its chemical/electrochemical conversion can move downstream with the produced water, accumulate and affect the ionomer, Pt surface, and the ORR at the outlet of the MEA resulting in a non-homogeneous performance.

Fig. 2 presents spatial EIS data for the cell exposed to $\mathrm{CH}_{3} \mathrm{Br}$ and the blank test. Initial EIS spectra were recorded during operation with pure air and consisted of a high-frequency cathode loop due to a charge transfer resistance and a double layer capacitance of oxygen reduction and a low-frequency arc attributed todiffusion limitations inthe cathode [74]. The low-frequency diffusion loop increased in diameter from the inlet to the outlet due to the progressive consumption of $\mathrm{O}_{2}$ and water production (Fig. 2 b). The injection of $\mathrm{CH}_{3} \mathrm{Br}$ into the air steam did not result in any noticeable changes tothe spatial EISduring the first $20 \mathrm{~h}$. Cathode charge transfer and mass transfer resistances for segments 1-6 only increased after $30 \mathrm{~h}$ of exposure. For outlet segments 7-10, an increase in the EIS response was observed after $45-50 \mathrm{~h}$ of bromomethane poisoning. A longer cathode exposure to $\mathrm{CH}_{3} \mathrm{Br}$ led to a slight increase in charge and mass transfer resistances for all segments and the appearance of a lowfrequency inductance for segments 6-10 at steady state ( $\sim 80 \mathrm{~h}$ exposure to $\mathrm{CH}_{3} \mathrm{Br}$ ).

Two successive electron transfer steps involving the formation of an adsorbed intermediate species were proposed as a general mechanism explaining the appearance of low-frequency inductance [75]. The subsequent ideas and models regarding the inductive behavior were developed later in other 
studies[76-79]. In fuel cell application,the low-frequency inductance was found during operation with ahydrogencontaining $\mathrm{CO}[68,80-82]$ and for direct methanol fuel cells (DMFCs), where $\mathrm{CO}$ is produced as an intermediate of $\mathrm{CH}_{3} \mathrm{OH}$ oxidation [83-85]. So, the inductance was observed when there was a slow potential dependent oxidation of $\mathrm{CO}$ to $\mathrm{CO}_{2}$ together with fasthydrogen oxidation at the anode. PEMFC exposed to air impurities $\left(\mathrm{C}_{2} \mathrm{H}_{2}, \mathrm{CH}_{3} \mathrm{CN}\right)$ also demonstrated the low-frequency inductance at potentialsfavoring contaminant electroreduction, which occurred in parallel with oxygen reduction and decreased its faradaic efficiency $[22,23]$. Thus, the low-frequency inductance during $\mathrm{CH}_{3} \mathrm{Br}$ exposure indicates on presence of subsequentelectrochemical reactions.

Continued operation with pure air after stopping the introduction of bromomethane to the air stream did not result in a self-recovery of performance, which is in agreement with the voltage and current data (Fig. 1 a, b and Fig. 2 a). The EIS of the PEMFC operated with pure air revealed a steady performance. The cathode charge transfer and diffusion resistances for segments 1-8 did not changeover $235 \mathrm{~h}$; there was a slight increase in the mass transfer resistances for segments 9-10, most likely due to water accumulation at the outlet of the MEA.
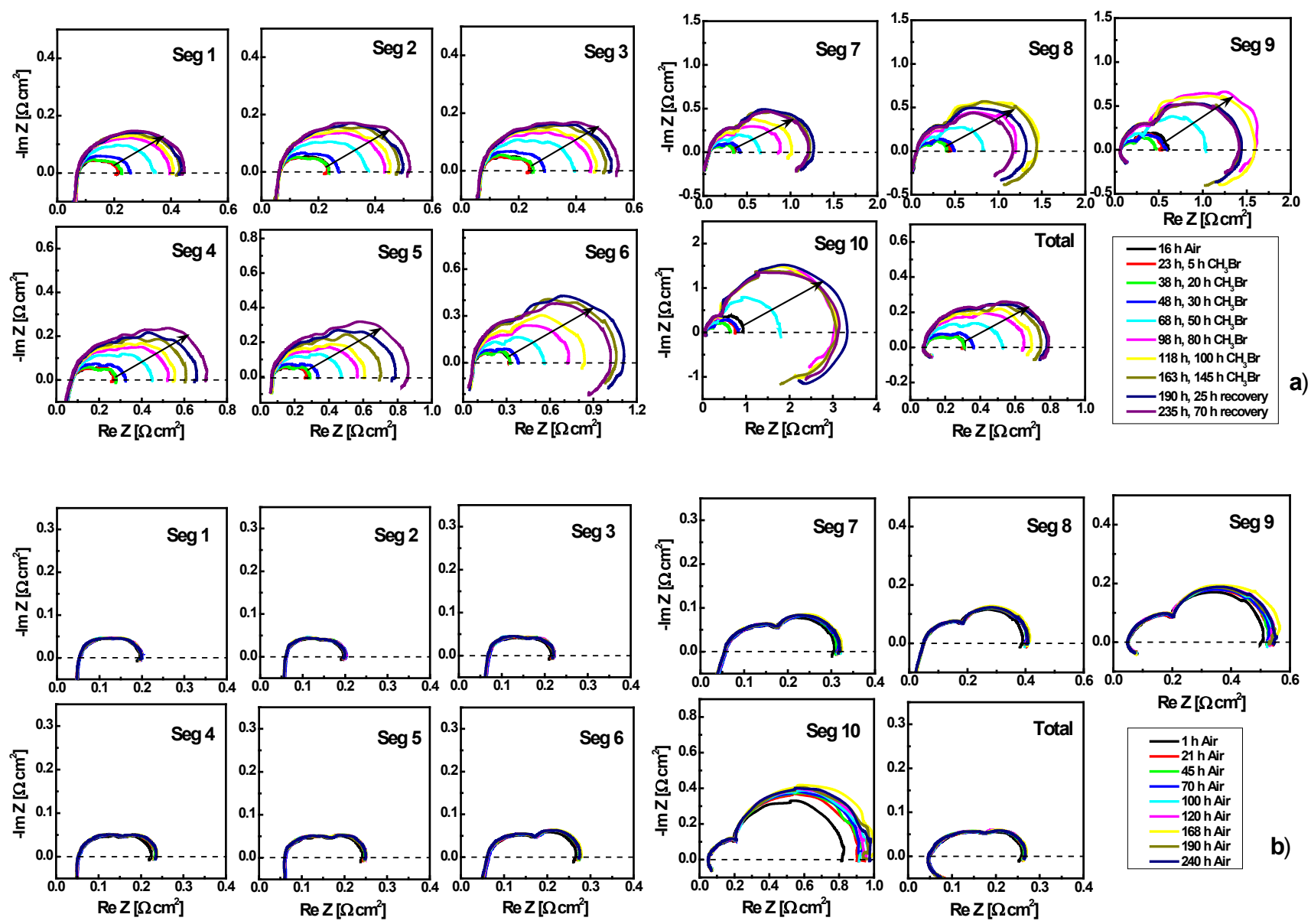

Fig. 2. EIS for segments 1-10 and the overall cell with $5 \mathrm{ppm} \mathrm{CH}_{3} \mathrm{Br}$ exposure (a) and without an air contaminant (b) at $1.0 \mathrm{~A} \mathrm{~cm}^{-2}$.Anode/cathode: $\mathrm{H}_{2} /$ air, $1.059 / 2.5221 \mathrm{~min}^{-1}, 100 / 50 \% \mathrm{RH}$, 48.3/48.3 $\mathrm{kPa}_{\mathrm{g}}, 80^{\circ} \mathrm{C}$. 


\subsection{A comparison of beginning of test (BOT) and end of test (EOT)ECA and performance}

A comparison of theBOT and EOT data was first performed in terms of ECA. CV measurements were conducted after $\mathrm{H}_{2} / \mathrm{N}_{2}$ and $\mathrm{N}_{2} / \mathrm{N}_{2}$ purges at the anode and cathode. During the purge, the cell voltage decreased to $\sim 0.1 \mathrm{~V}$ and the cell temperature reduced from 80 to $35^{\circ} \mathrm{C}$. Fig. 3demonstrates theinitial (BOT) as well as after exposure to $\mathrm{CH}_{3} \mathrm{Br}\left(\mathrm{EOT}, \mathrm{CH}_{3} \mathrm{Br}\right)$ and the blank test (EOT, air) $\mathrm{CV}$ profiles for the anode and cathode. The anode and cathode $\mathrm{CV}$ for the $\mathrm{CH}_{3} \mathrm{Br}$ case showed that after contaminant exposure there was a positive shift in the oxidation/reduction peaks of the adsorbed oxygen species $\mathrm{OH}_{\mathrm{ads}}(\sim 0.82 \mathrm{~V})$ and a $20 \mathrm{mV}$ negative shift in the peak positions in the hydrogen adsorption/desorption region (0.08-0.4 V). Exposure to $\mathrm{CH}_{3} \mathrm{Br}$ in the air resulted in $\mathrm{Pt}$ surface area loss for both electrodes. The ECA loss is clearly indicated by a current decrease in the hydrogen $(0.08-0.4 \mathrm{~V})$ and oxygen (0.4-0.9 $\mathrm{V}$ and $0.65-1.2 \mathrm{~V}$ for the cathodic and anodic parts, respectively) adsorption/desorption regions. It appeared that $\mathrm{CH}_{3} \mathrm{Br}$, its intermediates, and derivatives affected not only the cathode but also the anode catalysts. The anode ECA decreased from 84.9 to $36.4 \mathrm{~m}^{2} \mathrm{~g}^{-1}$ (i.e., $57.1 \%$ loss) and the cathode ECA declined from 84.1 to $40.4 \mathrm{~m}^{2} \mathrm{~g}^{-1}(51.9 \%)$.
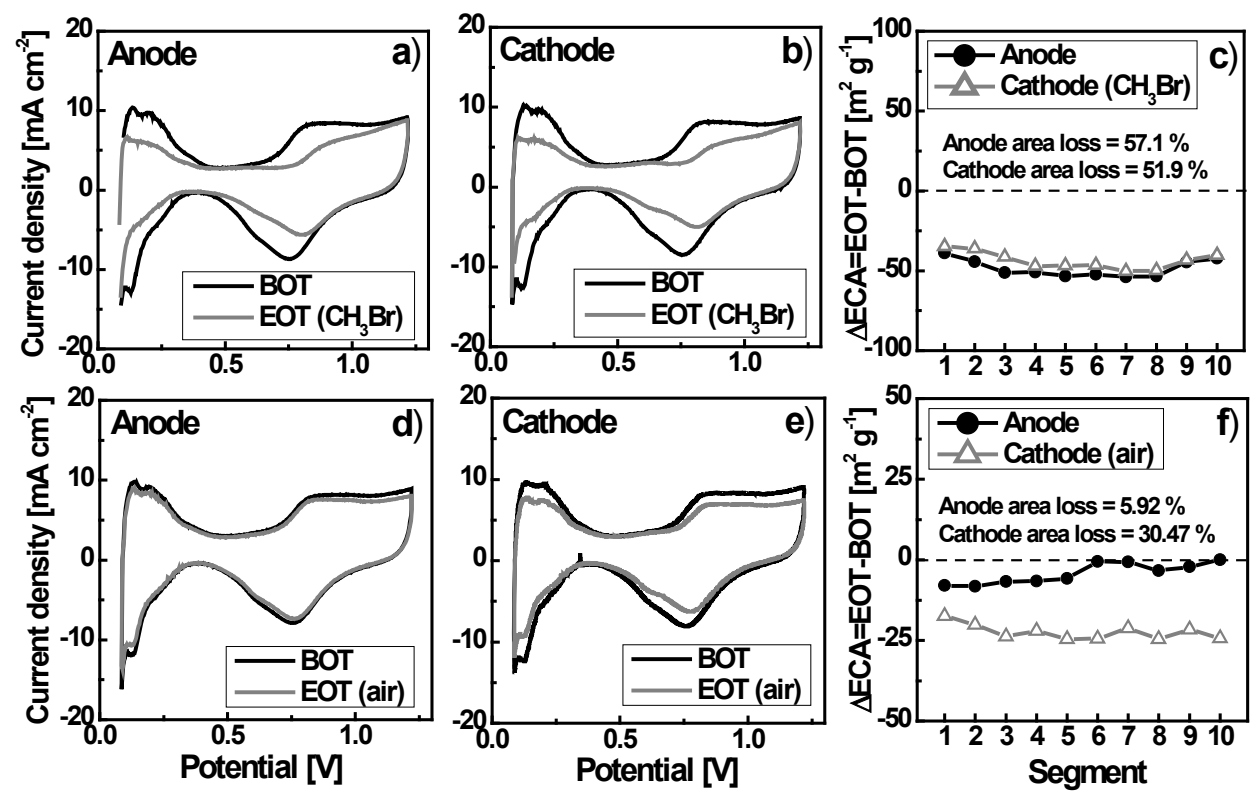

Fig. 3. CV curves measured for the whole cell: a) and b) - anode and cathode after $\mathrm{CH}_{3} \mathrm{Br}$ exposure; d) and e) - anode and cathode at the blank test. Distributions of the anode and cathode ECA differences between the values (c) after (EOT) and before (BOT) $\mathrm{CH}_{3} \mathrm{Br}$ exposure and (f) blank tests. Anode/cathode: $\mathrm{H}_{2} / \mathrm{N}_{2}, 0.75 / 0.751 \mathrm{~min}^{-1}, 100 / 100 \% \mathrm{RH}, 35^{\circ} \mathrm{C}, 0 / 0 \mathrm{kPa}, 20 \mathrm{mV} \mathrm{s}{ }^{-1}$.

A delay in the formation of $\mathrm{OH}_{\text {ads }}$ can be attributed tothe adsorption of negatively charged ions on $\mathrm{Pt}$ [43, 86-89] and a similar observation was reported for PEMFC poisoned by $\mathrm{Cl}^{-}[14,15]$. Previous detailed studies on theimpactsof $\mathrm{Br}^{-}$on ORR showed a remarkable resemblance to our results[35, 41$44,86]$. PEMFC operation with pure air did not lead to any significant changes in the anode and cathode CV curve peak locations (Fig. 3 d, e). The anode ECA loss was only 5.9\% from 71.7 to $67.5 \mathrm{~m}^{2} \mathrm{~g}^{-1}$. However, a noticeable decrease in the cathode ECA was found: $73.6 \mathrm{vs} 51.2 \mathrm{~m}^{2} \mathrm{~g}^{-1}$, which 
corresponds to a $30.5 \%$ loss and could have originated from the long-term operation for 235 h(Fig. 3 e).

The distributions of the anode and cathode ECA differences after contamination and blank tests are presented in Fig. $3 \mathrm{c}$ ) and f). A decrease in the anode and cathode ECA after exposure to $\mathrm{CH}_{3} \mathrm{Br}$ was uniform for all of the segments in the range of $45-50 \mathrm{~m}^{2} \mathrm{~g}^{-1}$. Operation with pure air led to a slight anode ECA loss for inlet segments 1-5 $\left(\sim 7-10 \mathrm{~m}^{2} \mathrm{~g}^{-1}\right)$, while the outlet was not affected. The opposite trend was observed for the cathode when the ECA loss increased downstream from 17 to $25 \mathrm{~m}^{2} \mathrm{~g}^{-1}$. This pattern in the cathode ECA behavior could be associated with thelong-term operation,water accumulation and non-uniform conditions along the flow field.
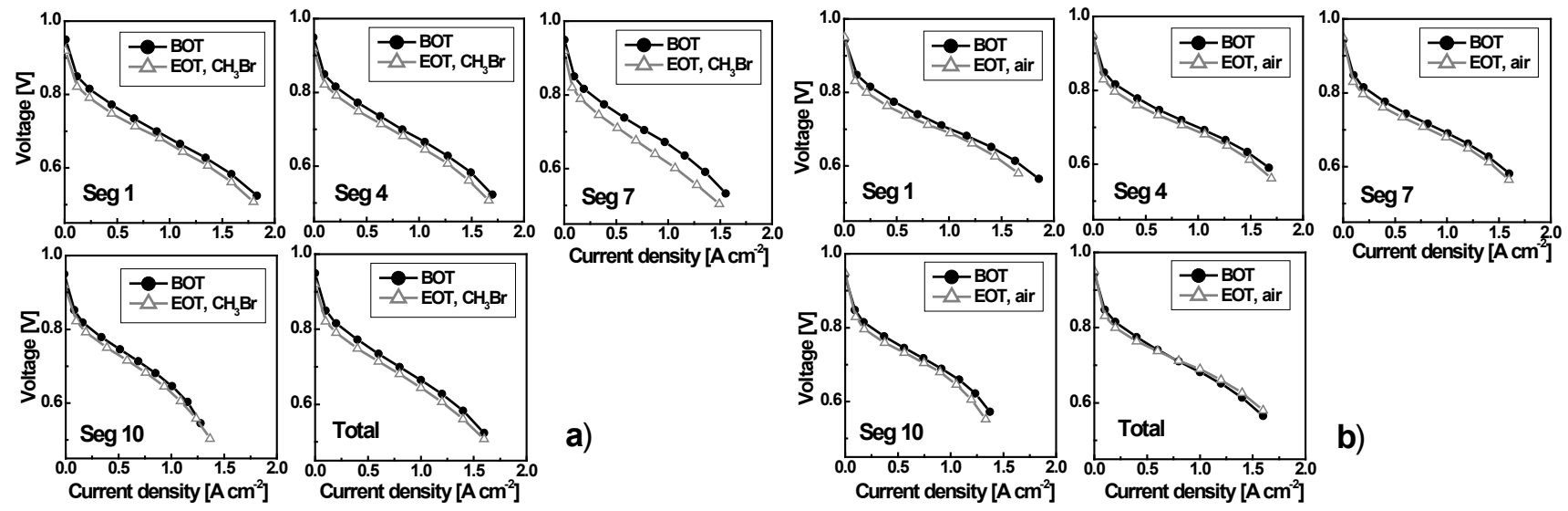

a)

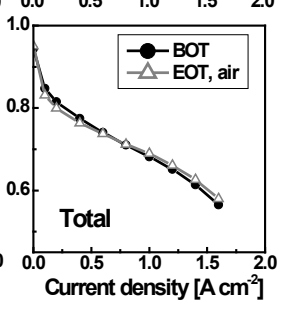

b)

Fig. 4. VI curves for segments $1,4,7,10$ and for the whole cell before (BOT) and after (EOT) contamination (a) and blank tests (b).Polarization curves were recorded after $\mathrm{CV}$ measurements and $\mathrm{H}_{2} / \mathrm{N}_{2}$ purge. Anode/cathode: $\mathrm{H}_{2} /$ air, $2 / 2$ stoichiometry, $100 / 50 \% \mathrm{RH}, 48.3 / 48.3 \mathrm{kPa}_{\mathrm{g}}, 80^{\circ} \mathrm{C}$.

Table 1. ECA and performance change after $\mathrm{CH}_{3} \mathrm{Br}$ exposure and blank tests.

\begin{tabular}{lllll}
\hline Test & \multicolumn{2}{c}{$\Delta$ ECA $[\%]$} & $\Delta$ Voltage $[\mathrm{mV}]$ & Voltage losses [mV] \\
\cline { 2 - 3 } & Anode & Cathode & & \\
\hline 5 ppm $\mathrm{CH}_{3} \mathrm{Br}$ & -57.1 & -51.9 & $15-50$ & Activation: $10-40$ \\
Blank & -5.9 & -30.5 & $10-25$ & Activation: $10-20$ \\
\hline
\end{tabular}

Fig. 4 a) compares the spatial cell performance before (BOT) and after the $\mathrm{CH}_{3} \mathrm{Br}$ test(EOT, $\mathrm{CH}_{3} \mathrm{Br}$ ). Polarization curves for BOT and EOT were recorded after $\mathrm{CV}$ measurements and $\mathrm{H}_{2} / \mathrm{N}_{2}$ purge.It is clear that $\mathrm{CH}_{3} \mathrm{Br}$ poisoning resulted in a decrease in the local MEA performance and voltage loss varies in the range of $15-50 \mathrm{mV}$. The observed performance lossis likely caused by the impacts of the impurity and otherdegradation mechanisms. To separate them,BOT and EOT results of the blank test wereanalyzed, and Fig. 4 b) shows the polarization curves for the same segments. A long-term PEMFC operation also resulted in slightperformance loss of 10-25 mV. A comparison of these two sets of data revealed the negative impact of $\mathrm{CH}_{3} \mathrm{Br}$ and its derivatives on PEMFC. The spatial fuel cell performances were examined in terms of activation, ohmic and mass transfer overpotentials, as described in [56] (Table 1). The data showed that the performance loss is mainly determined by increased activation overpotential due to decreased ECA, and the exposed sample was affected to a greater extent. 


\subsection{SEM and TEM characterization}

To understand the decreased catalyst ECA, texture and structure of the electrodes as well as the anode and cathode catalysts were analyzed by SEM and TEM. Cross-sections of the fresh catalyst coated membrane (CCM) and different locations (segments 1, 5 and 10) of the tested MEAs were evaluated by SEM (Fig. 5 a-c).
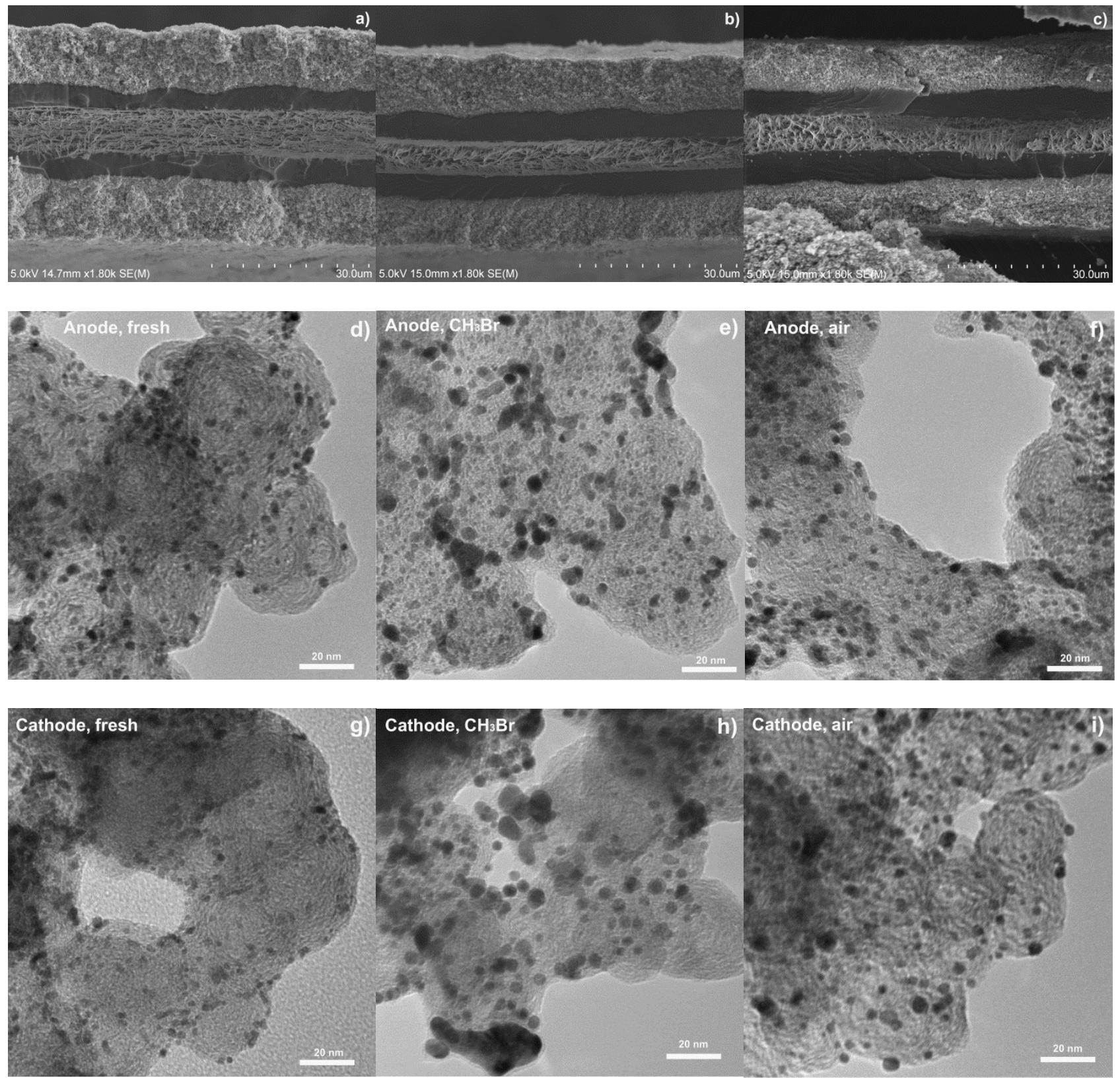

Fig. 5. SEM images of freshCCM (a), exposed to $\mathrm{CH}_{3} \mathrm{Br}$ (b) and operated with pure air (c). TEM images of $\mathrm{Pt} / \mathrm{C}$ - fresh anode (d) and cathode (g);MEA exposed to $\mathrm{CH}_{3} \mathrm{Br}$ : anode (e) and cathode (h);MEA operated with pure air: anode (f) and cathode (i).

A comparison of the SEM images at different locations within one sample did not reveal significant changes in the morphology and texture of the membrane and electrodes downstream. Analysis of the 
three different MEA samples showed that the initial membrane thickness was 16-18 $\mu \mathrm{m}$ (Fig. 5 a) and it remained constant after the tests (Fig. $5 \mathrm{~b}$ and c). A slight decrease in the electrode layer thickness from 10-12 to 9-11 $\mu \mathrm{m}$ was found after the tests, which is likely due to the compression of MEA in the hardware. Careful observation of the CCM texture and morphology did not provide any signs of corrosion or electrode structure damage, so the ECA decrease is mainly attributed to changes in the catalyst, not the electrode morphology.

The Pt particle growth after exposure to $\mathrm{CH}_{3} \mathrm{Br}$ was confirmed by TEM analysis of the catalyst samples scraped from the anode and cathode CCM surfaces at different locations (segments 1, 5, and 10). We did not find a significant effect of location on Pt particle size or distribution, so these parameters are nearly uniform downstream for the anode and cathode. Fig. 5 (d-i) shows the TEM images of the $\mathrm{Pt} / \mathrm{C}$ catalysts from the fresh, exposed to the $\mathrm{CH}_{3} \mathrm{Br}$ and non-poisoned MEAs.

The Pt particles from the anode and cathode in the fresh CCM sample had an average size of 2.4 \pm 0.6 $\mathrm{nm}$. The particles were uniformly distributed on the surface of the carbon support and were well dispersed (Fig. $5 \mathrm{~d}$ and g). A noticeable growth in the Pt size for both the anode and cathode was observed for the $\mathrm{CH}_{3} \mathrm{Br}$ exposed sample (Fig. 5 e and h), which was confirmed by the particle size distribution analysis (Fig. 6) and XPS. The particles in the cathode and anode had a size of $3.8 \pm 1.3 \mathrm{~nm}$ and $3.3 \pm 1.3 \mathrm{~nm}$, respectively. With the broad distribution, even particles with a diameter greater than $10 \mathrm{~nm}$ were observed. The cathode sample taken from the MEA operated with pure air had an increased metal particles size $(3.5 \pm 1.2 \mathrm{~nm})$ in comparison to the fresh sample (Fig. $5 \mathrm{i})$. At the same time, the anode catalyst for the same sample showed only a slight increase in the Pt size to $2.7 \pm 0.9 \mathrm{~nm}$.
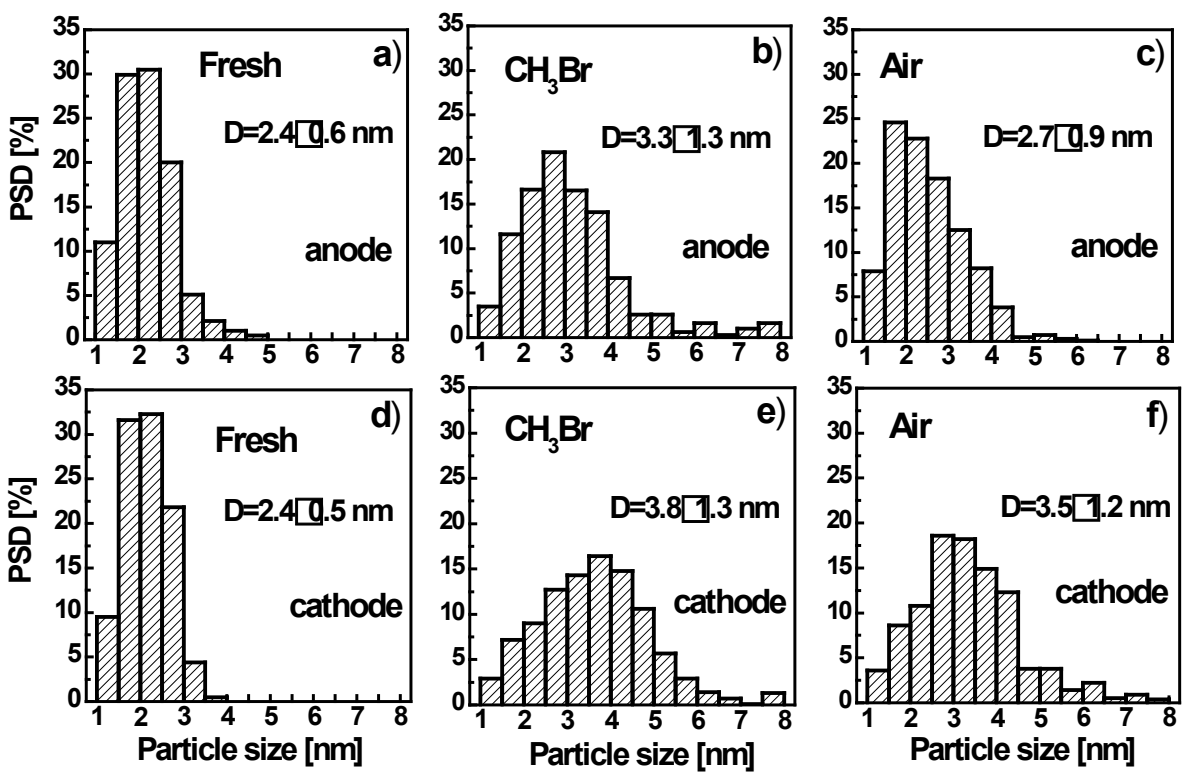

Fig. 6. PSD of Pt/C: fresh anode (a) and cathode (d), exposed to $\mathrm{CH}_{3} \mathrm{Br}$ anode (b) and cathode (e), and operated without air contamination anode (c) and cathode (f). 


\subsection{XPS studies}

The anode and cathode surface chemical composition of the fresh, blank and exposed to $\mathrm{CH}_{3} \mathrm{Br}$ samples was obtained by XPS. Three segments (1,5 and 10) from the blank and contaminated samples were analyzed. Table 2 shows the elemental composition and relative speciation of platinum, while Fig.7 (a-f)demonstrates high-resolution Pt 4f and Br 3p spectra fromfresh MEA and segment 1 from both the blank and exposed cathodes.

\section{Cathode}
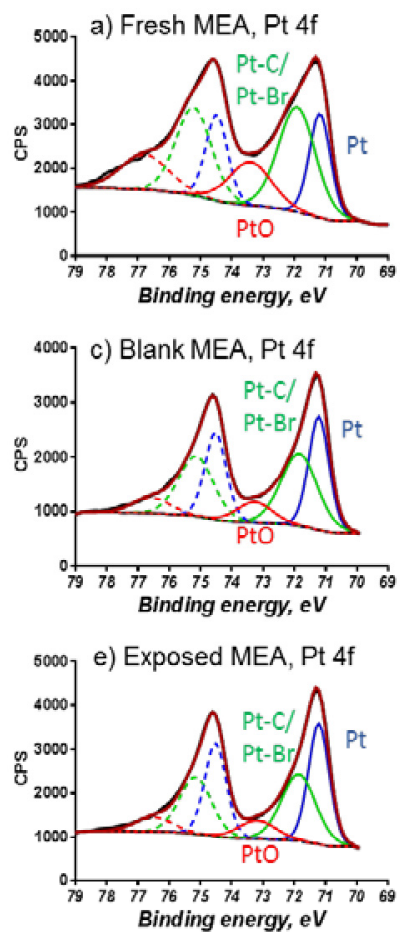
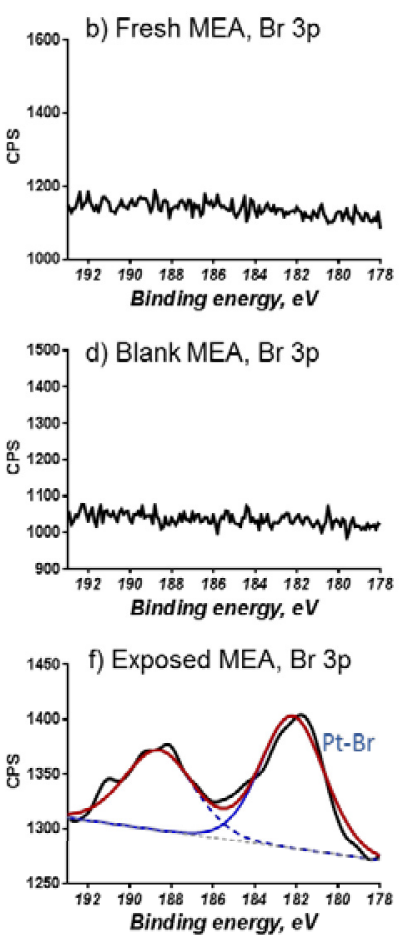

Anode
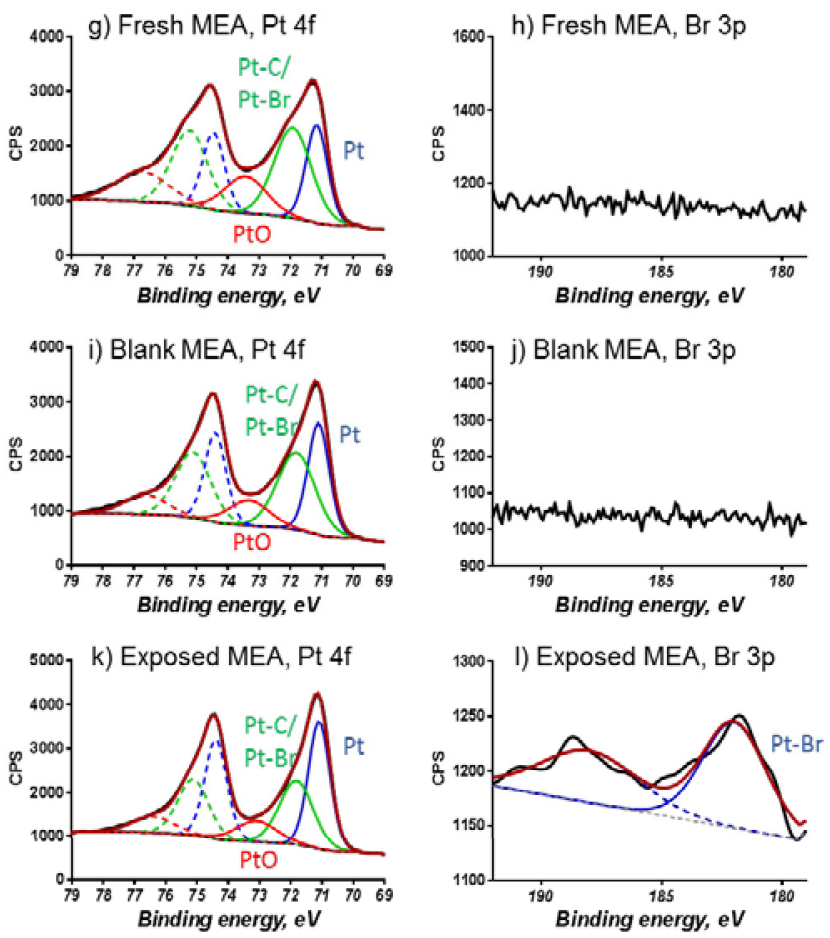

Fig. 7. High-resolution cathode $\mathrm{Pt}$ 4f (a, c and e) and $\mathrm{Br} 3 \mathrm{p} \mathrm{(b,} \mathrm{d}$ and $\mathrm{f}$ ) spectra for fresh, blank and exposed MEA; and anode $\mathrm{Pt} 4 \mathrm{f}(\mathrm{g}, \mathrm{i}$ and $\mathrm{k})$ and $\mathrm{Br} 3 \mathrm{p}(\mathrm{h}, \mathrm{j}$ and $\mathrm{l})$ for fresh, blank and contaminated MEA (segment 1).

An increase in the overall amount of carbon and a decrease in the contents of $\mathrm{F}$ and Pt were observed for the blank and exposed cathodes. Additionally, an increase in the $\mathrm{S} / \mathrm{F}$ ratio indicated the segregation of the $\mathrm{SO}_{3}$ fragments to the surface, depletion of the fluorinated backboneof the ionomer and itsdegradation, which became more pronounced for the poisoned MEA.Since the degradation of perfluorosulfonic acid polymer is usually caused by the presence of ${ }^{\circ} \mathrm{OH},{ }^{\circ} \mathrm{OOH}$, and $\mathrm{H}_{2} \mathrm{O}_{2}$, this observation strongly supports the fact, that $\mathrm{CH}_{3} \mathrm{Br}$ exposure results in increased production of radical species and enhanced radical-induced ionomer destruction. The exposed cathode had a $\mathrm{Br}$ signal, and its concentration was in the range of $0.10-0.34$ at. \%. The high-resolution $\mathrm{Br} 3 \mathrm{p}_{3 / 2}$ spectrum was present as a single broad peak at a binding energy of $\sim 182.0-182.3 \mathrm{eV}$. This binding energy was specific to chemisorbed $\mathrm{Br}^{-}$on platinum and also to bromomethane adsorbed on $\mathrm{Pt}$ through the $\mathrm{Br}$ atom, which corresponded to the reported values [90,91]. Segment 10 had a smaller amount of 
chemisorbed $\mathrm{Br}$ but it had the largest changes in composition due to the deterioration of the electrode.An increase in the carbon and decrease in both the fluorine and sulfur point toward a loss of ionomer from the catalyst layer for this segment, whichwas also confirmed by smaller changes in the $\mathrm{S} /$ Fratio than for others.A significant reduction in the $\mathrm{Pt}$ with a decrease inplatinum oxide $(\mathrm{PtO})$ and $\mathrm{Pt}$ coordinated to carbon (Pt-C)was observed for both the blank and contaminatedcathodes. $\mathrm{Pt}-\mathrm{Br}$ also contributed to the same binding energy as the Pt-C masking a larger loss of Pt coordinated to carbon.Moreover, theMEA exposed to $\mathrm{CH}_{3}$ Brwas characterized by a slightly larger degree of $\mathrm{Pt}$ reduction, which indicates on thelarger particle size of the catalyst.

To see whether $\mathrm{CH}_{3} \mathrm{Br}$ diffuses to the anode from the cathode, the anode of the same segments of the blank and exposed MEAs were analyzed (Table 3 and Fig. 7 (g-l)). The changes in the chemical composition detected on the anode are similar to that for the cathode but to a lessextent. A small increase in the relative carbon concentration and a decrease in the fluorine content were detected for the blank and exposed anodes. In the anode exposed to $\mathrm{CH}_{3} \mathrm{Br}$, the largest decrease in $\mathrm{Pt}, \mathrm{F}$ and Swas present in segment 10 and was accompanied by the greatest increase in the carbon content.The stability of the ionomer was supported by the lack of any changes to the $\mathrm{S} / \mathrm{F}$ and $\mathrm{Pt} / \mathrm{F}$ ratios for the anodes of segments 1 and 5, while segment 10 had the largest degradation and/or loss of ionomer. $\mathrm{Br}$ was detected on the anode of the exposed MEA but in smaller amounts than in the cathode (0.13-0.17 at. $\%)$. A decrease in the bromine concentration at both electrodes of segment 10 was explained by the fact that the inlet of the MEA was affected by the contaminant to a greater extent than the outlet. At the same time, a significant loss of ionomer was found for segment 10 at both electrodes under $\mathrm{CH}_{3} \mathrm{Br}$ exposure,indicatinga non-homogeneous degradation and eventually causing redistribution in local performances (Fig. 1b), which might be a subject requiring further investigations.

From Pt speciation, it was clear that the partial reduction of Pt happened during the test and platinum oxide decreased in the anode for all segments ofthe blank MEA. A very heterogeneous final chemistry was determined for the exposed anode. Segment 1was characterizedby the highest amount of detected chemisorbed $\mathrm{Br}$ and the lack of any loss in the overall Pt; however, the Pt that was left after the test was more reduced due to the formation of larger metal particles. In segments 5 and 10, the formation of oxides was evident as a result of the oxidation of Pt that was chemically coordinated with the carbon support. This was also accompanied by larger oxygen detected in these segments. Oxidation of the carbon support in these segments caused the detachment of Pt and formation of Pt oxides. The obtained XPS data provided evidence for the presence of $\mathrm{Br}$ on the cathode and anode under the bromomethane exposure of PEMFC, the growth of the Pt particle size and ionomer degradation, which was in full support of the electrochemical and microscopic findings. 
Table 2. XPS elemental composition and $\mathrm{Pt}$ speciation for the fresh, blank and $\mathrm{CH}_{3} \mathrm{Br}$ exposed cathodes.

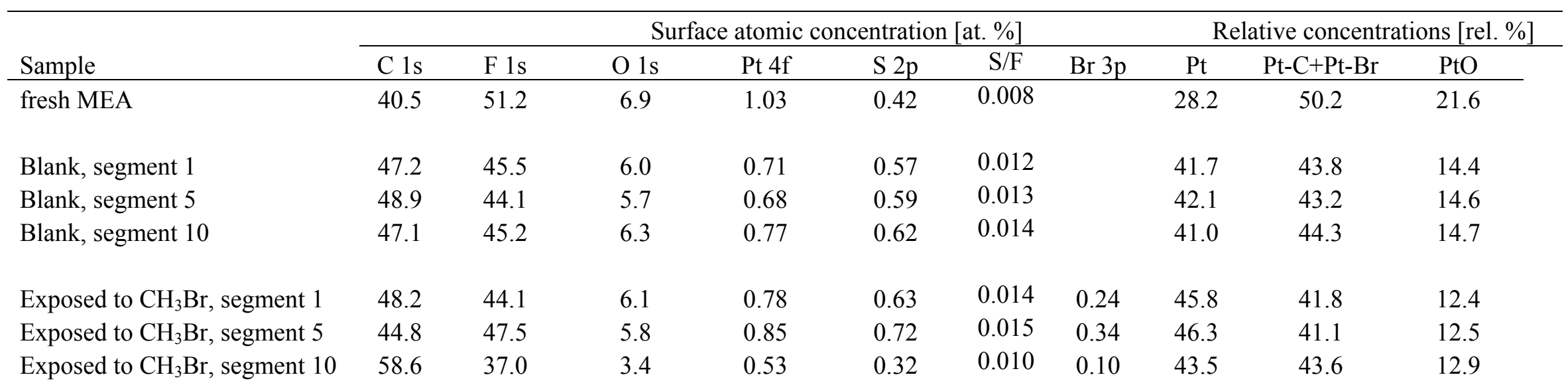

Table 3. XPS elemental composition and $\mathrm{Pt}$ speciation for the fresh, blank and $\mathrm{CH}_{3} \mathrm{Br}$ exposed anodes.

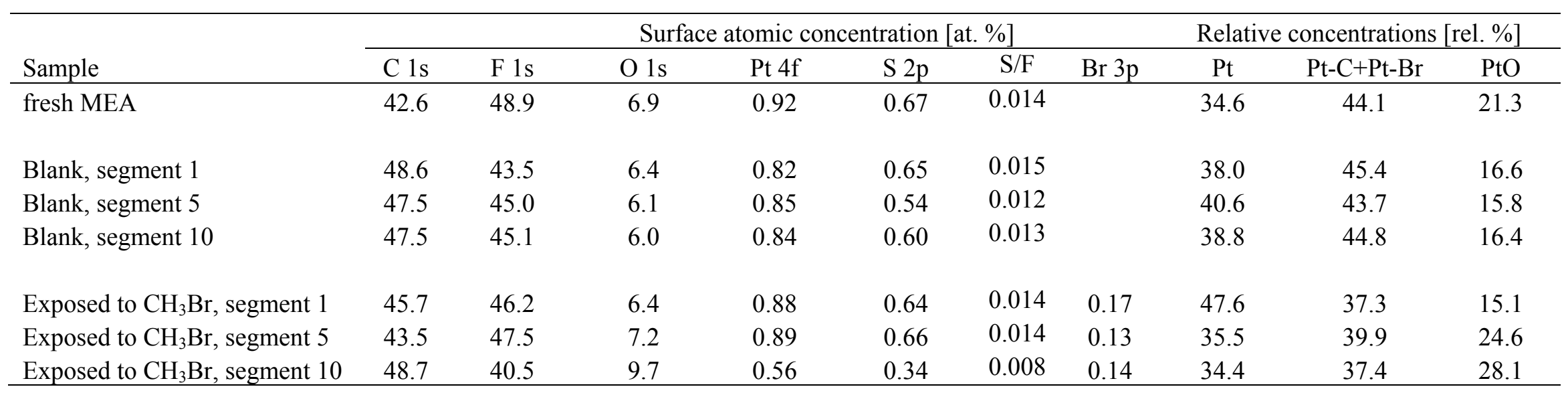




\section{Discussion}

PEMFC exposure to $\mathrm{CH}_{3} \mathrm{Br}$ in the air stream resulted in performance degradation that could not be recovered by switching to a pure air operation. Our data revealed that there are two main contributing factors to the cell performance under exposure of bromomethane. The first factor isan impact ofthe adsorption of $\mathrm{CH}_{3} \mathrm{Br}$ and its derivatives on the $\mathrm{Pt}$ surface and the second is a decrease in ECA due to $\mathrm{Pt}$ particles growth.

Studies of $\mathrm{CH}_{3} \mathrm{Br}$ adsorption on $\mathrm{Pt}$ (111) by reflection absorption infrared, thermal programmed desorption spectroscopies, and scanning tunneling microscopy demonstrated that at low coverages, bromomethane occupies only the top sites while with an increase in coverage, less stable multicoordinate sites start to be taken $[31,33]$. The preferred orientation of $\mathrm{CH}_{3} \mathrm{Br}$ at the saturation coverage of the 0.22-0.25 monolayer (ML) was aligned along the surface normal [31, 33, 92], and $\mathrm{CH}_{3} \mathrm{Br}$ bound to $\mathrm{Pt}$ through $\mathrm{Br}$ with a symmetryof less than $\mathrm{C}_{3 \mathrm{v}}$ [93]. The adsorption energy of $\mathrm{CH}_{3} \mathrm{Br}$ decreases monotonically from $0.62 \mathrm{eV}$ at the $0.12 \mathrm{ML}$ to $0.33 \mathrm{eV}$ at the $0.22 \mathrm{ML}$ [31].

Dissociation of $\mathrm{C}-\mathrm{Br}$ bond of $\mathrm{CH}_{3} \mathrm{Br}$ adsorbed onto Pt (111) with theformation of $\mathrm{CH}_{3}$ and $\mathrm{Br}$ was found to occur under photochemical conditions [94, 95], whileheat treatment did not result in the decomposition of the adsorbed $\mathrm{CH}_{3} \mathrm{Br}$ [93]. In comparison to the photochemical setups, the environmental conditions at the fuel cell operationwere completely different; theymost likely lead to the hydrolysis of $\mathrm{CH}_{3} \mathrm{Br}$ with the production of $\mathrm{Br}^{-}$, as previously shown [28-30]:

$\mathrm{CH}_{3} \mathrm{Br}+\mathrm{H}_{2} \mathrm{O} \rightarrow \mathrm{CH}_{3} \mathrm{OH}+\mathrm{H}^{+}+\mathrm{Br}^{-}$

with a rate constant of $3 \cdot 6 \cdot 10^{11} \mathrm{e}^{-12300 / \mathrm{T}} \mathrm{s}^{-1}$ [30], which leadstoa time constant for the bromomethanehydrolysis of $1-2 \mathrm{~h}$ at $80^{\circ} \mathrm{C}$. Our XPS and electrochemical results confirmed thepresence of $\mathrm{Br}$ adsorbed on the Pt particles. The adsorption energy of bromine on $\mathrm{Pt}$ (111) was estimated by the density functional theory calculation and was found to be $2.86 \mathrm{eV}$ [96]. Moreover,adsorption of bromine on Pt was stronger than bromomethane. So, the initial delay in the voltage response within $9 \mathrm{~h}$ of exposure may be explained by the production of bromide ions at a noticeable concentration following the adsorption onto Pt (Fig. 1 a).

The electrochemistry of bromide on Pt single-crystal electrodes has been intensely studied for the last three decades. Cyclic voltammetry revealed hydrogen adsorption/desorption peaks at 0-0.3 V; a sharp reversible peak at $\sim 0.1-0.2 \mathrm{~V}$ that wasattributed to the reductive desorption of $\mathrm{Br}^{-}$; groups due toPt surface oxide formation and the corresponding reduction peaks and a current peak above $1.0 \mathrm{~V}$ due to halide oxidation [34-36, 39-43, 46, 86, 88,97, 98].

Thus, the bromide ion isstrongly adsorbed onto $\mathrm{Pt}$ as bromine at a wide range of potentials from $\sim 0.2$ to $\sim 1.0 \mathrm{~V}$ following the Langmuir-type adsorption $[35,43]$ or the Frumkin-Temkin isotherm [86] with maximum coverage of 0.42-0.7 ML [38-40, 43, 86-88]. Bromine coverage did not reach the full monolayer due to the repulsive interaction of partially negatively charged ions. Based on the RRDE results, this coverage was sufficient for the strong inhibition of oxygen-reductionreactions, leading to a negative shift in the ORR potential with noticeable $\mathrm{H}_{2} \mathrm{O}_{2}$ formation[41]. The workdemonstrated that $\mathrm{O}_{2}$ 
reduction does not proceed entirely through the 4-electron mechanism; it goes through the less efficient mixed pathway in which the 4- and 2-electron processes occur in parallel, generating $\mathrm{H}_{2} \mathrm{O}$ and $\mathrm{H}_{2} \mathrm{O}_{2}$, respectively. Thus, the state of the $\mathrm{Pt}$ surface depends on the competition between the adsorption/chemisorption of $\mathrm{Br}^{-}$and the formation of surface oxides. All of the electrochemical studies clearly demonstrated that $\mathrm{Br}^{-}$strongly suppresses the adsorption of $\mathrm{O}_{2}$ and the availability of the platinum sites needed to break the oxygen double bonds [34-36, 39-43, 46, 86-88].

In addition to the bromide impacts on the Pt surface chemistry and ORR, the second contributor is degradation due to a decrease in the ECA caused by the growth of platinum particles, which is supported by the TEM and XPS results. The observed ECA loss can be explained by two main mechanisms: particle agglomeration and Ostwald ripening through Pt dissolution, diffusion, and redeposition. The formation of stable complex ions with platinum are expected to favor Ostwald ripening and lead to noticeable Pt size growth and a decrease in the ECA. Our findings allowed us to assume that Ostwald ripening is possible and requires suitable anions for complexation with $\mathrm{Pt}$, insuring its dissolution. In our opinion, bromide seems to be such an anion because in its presence the following complexation reactions can occur [99, 100]:

$$
\begin{array}{ll}
\mathrm{Pt}+4 \mathrm{Br}^{-} \rightarrow\left[\mathrm{PtBr}_{4}\right]^{2-}+2 \mathrm{e}^{-} & \mathrm{E}^{0}=0.67 \mathrm{~V}(\mathrm{SHE}) \\
\mathrm{Pt}+6 \mathrm{Br}^{-} \rightarrow\left[\mathrm{PtBr}_{6}\right]^{2-}+4 \mathrm{e}^{-} & \mathrm{E}^{0}=0.66 \mathrm{~V}(\mathrm{SHE}) \\
{\left[\mathrm{PtBr}_{4}\right]^{2-}+2 \mathrm{Br}^{-} \rightarrow\left[\mathrm{PtBr}_{6}\right]^{2-}+2 \mathrm{e}^{-}} & \mathrm{E}^{0}=0.64 \mathrm{~V}(\mathrm{SHE}) \\
\mathrm{Pt} \rightarrow \mathrm{Pt}^{2+}+2 \mathrm{e}^{-} & \mathrm{E}^{0}=1.2 \mathrm{~V}(\mathrm{SHE})
\end{array}
$$

where $\mathrm{E}^{0}$ and SHE are the standard electrode potential and standard hydrogen electrode, respectively. Similar observations were reported for PEMFC poisoned by $\mathrm{Cl}^{-}$, where an increase in $\mathrm{Pt}$ particle size and the formation of an electrically isolated Pt band in the membrane were found [14-17].

The presence of bromine at the anode of the sample exposed to $\mathrm{CH}_{3} \mathrm{Br}$ is supported by the XPS data. Crossover of $\mathrm{Br}^{-}$from the cathode to the anode was not expected because negatively charged ions are rejected by Nafion. However, the observation of $\mathrm{Cl}^{-}$crossover by $\mathrm{Li}$ et al. [17] led us to theassumption that $\mathrm{Br}^{-}$might also diffuse through the mechanically reinforced Nafion membrane and affect the anode catalyst. Another explanation for the presence of $\mathrm{Br}^{-}$at the anode could be the diffusion of $\mathrm{CH}_{3} \mathrm{Br}$ through the membrane and its subsequent hydrolysis. Presumably, the concentration of bromomethane at the anode was less than at the cathode due to transport resistance, which diminishes the bromomethane impact on Pt particle growth (Fig. 5, 6).

The shape of the particle size distributionscan be used to determinea preferable mechanism of particle growth [101, 102] (Fig. 6). In the case of Ostwald ripening, PSD has a substantial tail on the smalldiameter side, and distribution was not above a certain finite particle size. Coalescence growth provides distribution with a tail at the larger-diameter side where it asymptotically approaches zero. The fresh anode and cathode were characterized by the slightly asymmetrical distributions around a maximum of $2.4 \mathrm{~nm}$ (Fig. $6 \mathrm{a}, \mathrm{d}$ ). PSDs of the anode and cathode catalysts after all of the tests have a pronounced tail on the larger particle size, which indicates particle growth through an agglomeration mechanism (Fig. 6 b, c, e, f). However, PSDs have more symmetry around the maximum for the anode 
and cathode exposed to $\mathrm{CH}_{3} \mathrm{Br}$ (Fig. $6 \mathrm{~b}$, e), which may be attributed to Ostwald ripening.

The different shapesofthe distributions implythat there were different mechanisms of particle growth: exposure to $\mathrm{CH}_{3} \mathrm{Br}$ appears to cause accelerated $\mathrm{Pt}$ growth through agglomeration and Ostwald ripening while operation with pure air results in particle coalescence as a dominant mechanism of Ptgrowth, which is supported by the electrochemical data (Table 1). The observed ECA losses for the anode and cathode after the blank test were 5.9 and $30.5 \%$, respectively, and can be attributed mainly to the particle coalescence that was demonstrated by PSD (Fig. 6 c, f). A noticeable cathode area decline of $\sim 30.5 \%$ compared to the anode might be connected to the accelerated particle growthunder the long-term operation under the conditions of high current with greater water production. The anode and cathode ECA losses of $\sim 52-57 \%$ after $\mathrm{CH}_{3} \mathrm{Br}$ poisoning indicated the contribution of Ostwald ripening to the particle size growth (Fig. 6. b, e). Dissolution and redeposition seem to drastically impact the anode PSD under $\mathrm{CH}_{3} \mathrm{Br}$ exposure and can account for $57.1 \%$ of the ECA loss, while for the cathode, Ostwald ripening appears to have a subsidiary role.

A comparison of an $\mathrm{E}^{0}$ of 0.64-0.67 V (electrochemical and complexation reactions of $\mathrm{Pt}$ and $\mathrm{Br}^{-}$,Eqs. 2-4) even with a compensated ohmic loss cell voltage of 0.37-0.67 V was not reasonable for several reasons:1) cell voltage needs to be converted to potentials vs. SHE instead of HRE for a comparison, 2) $E^{0}$ is reported for aqueous media ( $1 \mathrm{M}$ bromide solutions) and standard conditions, and 3$) \mathrm{E}^{0}$ does not take into account the effects of Pt crystallite size and contributions from the crystalline facets and edges, which can significantly reducethe Pt dissolution potential [103]. Moreover, a reduction of the dissolved $\left[\mathrm{PtBr}_{4}\right]^{2-}$ and $\left[\mathrm{PtBr}_{6}\right]^{2-}$ species by crossover hydrogen in the membrane or at the catalyst/membrane interface can generate electrically isolated $\mathrm{Pt}$ particles, such as a $\mathrm{Pt}$ band in the membrane [16, 104].

The impact of $\mathrm{CH}_{3} \mathrm{Br}$ on PEMFC is summarizedby the scheme presented in Fig. 8. The initial lack of any changes in the PEMFC response after the introduction of $\mathrm{CH}_{3} \mathrm{Br}$ was due to bromomethane hydrolysis during the first several hours of exposure. The subsequent adsorption of bromide/bromomethane on the Pt surface, and also the continuing $\mathrm{CH}_{3} \mathrm{Br}$ hydrolysis can explain the fast voltage degradation from 0.660 to $0.440 \mathrm{~V}$ within $45 \mathrm{~h}$ of injecting the contaminant (Fig. $1 \mathrm{a}, \mathrm{b}$ ). The gradual poisoning was reflected by a constant increase in the charge and mass transfer resistances detected by the spatial EIS (Fig. 2 a). The slow voltage decline from 0.440 to $0.335 \mathrm{~V}$ can be attributed to incipient catalystparticle growthaccelerated by $\mathrm{Br}^{-}$as well as thecontinued impact of the poisoning. The XPS observation of the depletion of $\mathrm{CF}_{2}$ and enrichment of the $\mathrm{SO}_{3}$ groups after the test indicated that Nafionhad short end chains due to radical-induced degradation, which may alter the interactions between the Pt particles and ionomer. As the Pt particles grew, the ionomer chains became shorter and causedpartial coverage of the Pt nanoparticle with Nafion.The partial coverage of Pt maycreatelocal partial flooding of the particle exposed to the open pore by water generated on the part of the Pt particle covered by Nafion, which will lead to a $\mathrm{pH}$ gradient and result in voltage drop, i.e., performance loss [105]. As soon as the cell voltage reached a steady state after $80 \mathrm{~h}$ of exposure, the spatial EIS revealed the formation of the low-frequency inductance for the outlet segments (Fig. 2 a). The low-frequency inductance demonstrated the presence of electrochemical processesthat have at least two elementarysteps. Because bromomethane and $\mathrm{Br}^{-}$were not directly involved in any of the 
electrochemical transformations at the operating potentials, ORR might cause the observed inductance. The formation of $\mathrm{H}_{2} \mathrm{O}_{2}$ as an intermediate product in 2-electron oxygen reduction was previously shown to account for the low-frequency inductive loop [106-108]. Therefore, in our case, $\mathrm{Br}^{-}$partially shifts the oxygen reduction to a 2-electron mechanism [41] and we could hypothesize that 2-electron ORR resulting in $\mathrm{OHand} \mathrm{H}_{2} \mathrm{O}_{2}$ formationmay explain the inductance and contribute to ionomer degradation, as was detected by XPS. In addition, a possible diffusion of $\mathrm{CH}_{3} \mathrm{Br}$ from the cathode to the anode could lead to $\mathrm{CH}_{3} \mathrm{OH}$ production through bromomethane hydrolysis and formation of $\mathrm{CO}$ in quite low concentration. The presence of carbon monoxide at the anode might also be an explanation for theobservation of low-frequency inductance [68, 75-85]. However, PEMFC operation at ahigh temperature usually mitigates $\mathrm{CO}$ effects.

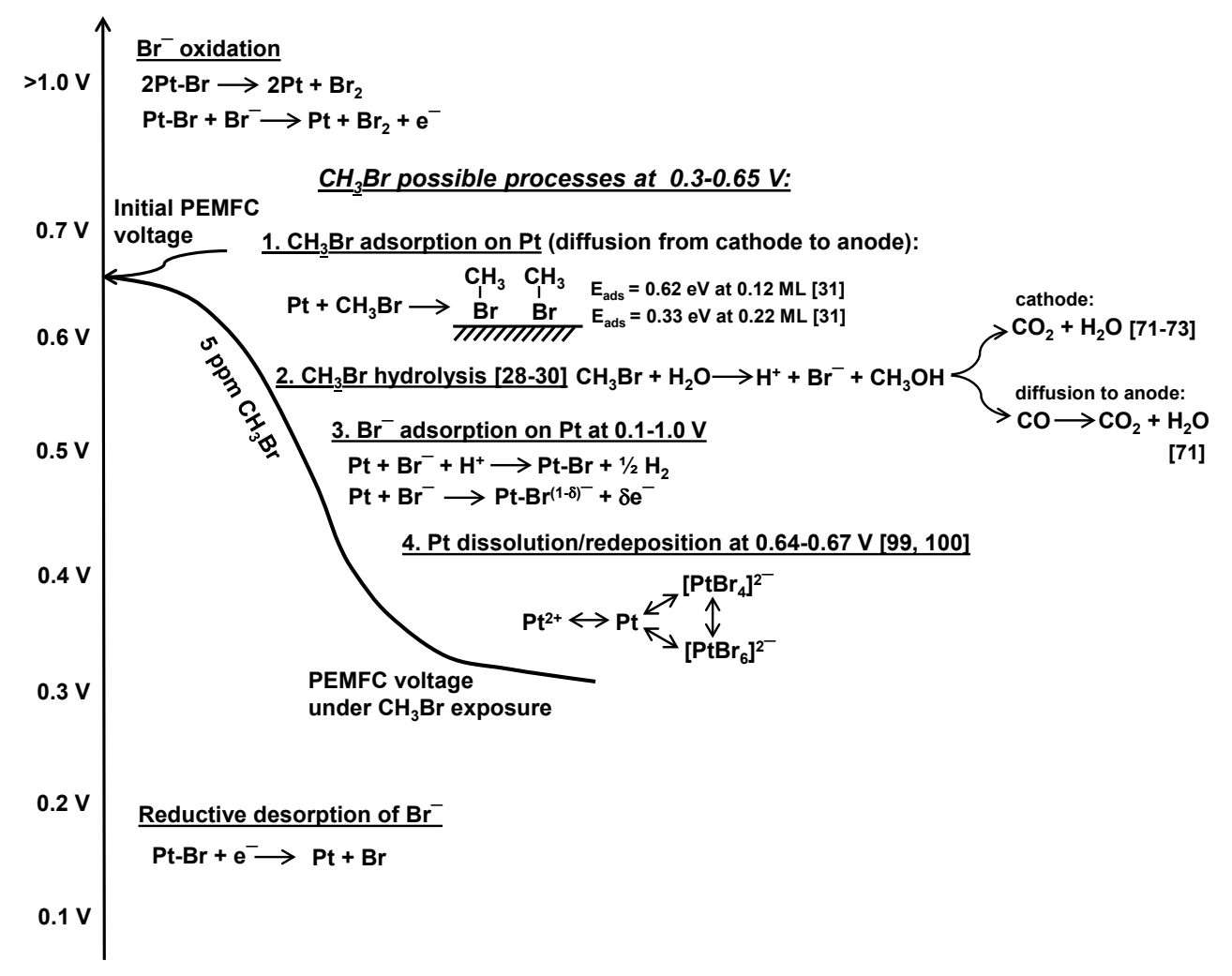

Fig. 8. Schematic of $\mathrm{CH}_{3} \mathrm{Br}$ possible processes at PEMFC operation.

The behavior of the current density distribution under $\mathrm{CH}_{3} \mathrm{Br}$ poisoning and recovery showed that the inlet segments had a slightly higher current density than the outlet segments: $1.25 \mathrm{vs} .0 .77 \mathrm{~A} \mathrm{~cm}^{-2}$, respectively (Fig. 1 b). The obtained order of the local performances was not fully understood and might be a subject for future work, but asimilar trend was previously observed for PEMFC operated with air and $20 \mathrm{ppm} \mathrm{CH}_{3} \mathrm{CN}$ and was explained by the electrochemical properties of acetonitrile and the formation of $\mathrm{NH}_{4}^{+}$[23]. Bromomethane hydrolysis occurs in the presence of water, so the hydrolysis seems to be more preferable at the outlet of the MEA, where produced $\mathrm{H}_{2} \mathrm{O}$ usually accumulates. We expect the accelerated formation of bromide at the outlet segments, their poisoning and a local loss of performance. This argument could explain the observed current distribution when the inlet segments have better performance than the outlet segments. However, a decrease in thebromine surface concentration downstream was detected by XPS (Tables 2, 3) and suggested the 
opposite trend in the local currents compared to what was detected. It appears that the adsorbed bromine onto Pt cannot be the only explanation for the local current behavior. On the other hand, the XPS data clearly revealed that, under the contaminant exposure, the outlet segments deteriorated severely compared to the others, negatively affecting the local performance, which might determine the current density order. The cell was operated in the galvanostatic conditions, which required thedraining of a constant current from the whole cell, and because the current of the outlet segments decreased, an increase in the current of the inlet segments happened.The current redistribution continued during the recovery period, suggesting the hydrolysis of the remained and adsorbed bromomethane.

The operation with pure air after $\mathrm{CH}_{3} \mathrm{Br}$ exposure did not recover the PEMFC performance (Fig. 1),presumablydue to the presence of the adsorbed $\mathrm{Br}$ on the $\mathrm{Pt}$ surface. As mentioned previously, bromide ions are strongly adsorbed onto Pt overa wide range of potentials $(\sim 0.2-1.0 \mathrm{~V})$ and can be removed through the reductive desorption at $\sim 0.1-0.2 \mathrm{~V}$ or oxidation to $\mathrm{Br}_{2}$ at potentials higher than $1.0 \mathrm{~V}$. A $\mathrm{H}_{2}$ and $\mathrm{N}_{2}$ purge at the anode and cathode decreased the cell voltage to $0.1 \mathrm{~V}$, which was sufficient for Br desorption and fuel cell recovery. Additionally, it explained the lack of any bromide reductive desorption peak at low potentials on the CV curves (Fig. 3). However, CV demonstrated some other features of $\mathrm{Br}^{-}$presence at low concentrations on the anode and cathode catalysts including a positive shift in the oxidation/reduction of the adsorbed oxygen species and a negative shift in the hydrogen oxidation/reduction region. In spite of these results, a comparison of BOT and EOT performance (Fig. 4) showed sufficient recovery of thefuel cell with a maximum performance loss of $50 \mathrm{mV}$. Based on our observations, it was possible to suggest that the $\mathrm{H}_{2}$ and $\mathrm{N}_{2}$ purge at an open circuit voltage (ocv) could restore the cell performance after exposure to a bromomethane- or bromidegenerating contaminant.

\section{Conclusion}

PEMFC localized performance under exposure of $5 \mathrm{ppm} \mathrm{CH}_{3} \mathrm{Br}$ was studied usingthe segmented cell system. Bromomethane poisoning led to a gradual cell voltage decrease from $0.650 \mathrm{~V}$ to 0.335 Vduring $80 \mathrm{~h}$ of contaminant injection and local current redistribution. The observed performance loss and spatial current behavior are explained by two major reasons: chemical adsorption of $\mathrm{CH}_{3} \mathrm{Br}$ and $\mathrm{Br}^{-}$on $\mathrm{Pt}$ and decrease in ECA.

The first factor is related to the impact of $\mathrm{Br}^{-}$, which originates from $\mathrm{CH}_{3} \mathrm{Br}$ hydrolysis under the fuel cell conditions. Another product of hydrolysis, methanol, can be oxidized at the cathode to $\mathrm{CO}_{2}$ and $\mathrm{H}_{2} \mathrm{O}$. Chemisorption of bromine and bromomethane at both the anode and cathode were detected by XPS and resulted in the suppression of $\mathrm{O}_{2}$ adsorption, inhibition of 4-electron ORR and shifting the mechanism to a less efficient combination of2- and 4-electron pathways. The second factor is anode and cathode ECA loss $(\sim 52-57 \%)$ caused by the growth of the Pt particle size through particle agglomeration and Ostwald ripeningaccompaniedby ionomer degradation. The formation of stable complex ions $\left[\mathrm{PtBr}_{4}\right]^{2-}$ and $\left[\mathrm{PtBr}_{6}\right]^{2-}$ favors the Pt dissolution and redeposition mechanism, while particle agglomeration is the dominant process for PEMFC operated with pure air. Spatial EIS revealed a constant increase in the charge and mass transfer resistances for all segments until a steady state was reached. The observed low-frequency inductance can be attributed to 2-electron ORR with the intermediate formation of $\mathrm{H}_{2} \mathrm{O}_{2}$. 
The cell did not restore its performance even after operation with pure air for $70 \mathrm{~h}$ due to the strongly adsorbed Br. However, the polarization curves measured after the $\mathrm{H}_{2} / \mathrm{N}_{2}$ purge of the anode/cathode at the ocvand CV scans revealed cell recovery and slight performance loss of $50 \mathrm{mV}$ due to the activation overpotential. The $\mathrm{H}_{2} / \mathrm{N}_{2}$ purge resulted in a cell voltage decrease of $0.1 \mathrm{~V}$, which is sufficient for the desorption of $\mathrm{Br}^{-}$and cell performance recovery. A subsequent or parallel step in the presence of liquid water would further increase the recovery by bromide removal. The obtained results clearly demonstrate that the fuel cell exposure to $\mathrm{CH}_{3} \mathrm{Br}$ should be limited to concentrations much less than 5 ppm due to serious fuel cell performance loss and lack of self-recovery. A decrease in $\mathrm{CH}_{3} \mathrm{Br}$ concentration to real atmospheric conditions (25 ppt - $1.2 \mathrm{ppb}$ ) might not cause negative impact even at long-term operation. However, a reduction of Pt loadings in PEMFCs electrodes below $0.1 \mathrm{mg} \mathrm{cm}^{-}$ ${ }^{2}$ makes them more sensitive to any impurities and requires further work to understand environmental tolerance of fuel cells with low Pt content.

\section{Acknowledgements}

The authors gratefully acknowledge the Center for Microengineered Materials and Hawaiian Electric Company,Department of Energy (award DE-EE0000467) and Office of Naval Research (award N00014-13-1-0463)for funding this work. The authors also thank Günter Randolf(GRandalytics) for the valuable support regarding the system operation and Tina Carvalho (University of Hawaii) for support of the SEM and TEM measurements.

\section{References}

[1] J.M. Moore,P.L. Adcock, J.B.Lakeman, G.O.Mepsted, The effects of battlefield contaminants on PEMFC performance,J. Power Sources85 (2000) 254.

[2] G. Mepsted, Investigation of the effects of air contaminants of SPFC performance. ETSU F/02/00172REP, DTI/Pub URN 01/905, UK Department of Trade and Industry, UK, 2001.

[3] O.A. Baturina, Y. Garsany, B.D. Gould, K.E.Swider-Lyons, in: H. Wang, H. Li, X.-Z. Yuan (Eds.)PEM fuel cell failure mode analysis; CRC Press, 2011, pp. 199-241.

[4] H. Li, J. Zhang, Z. Shi, D. Song, J. Zhang, J.in: H. Li, S. Knights, Z. Shi, J.W. Van Zee, J. Zhang (Eds) Proton Exchange Membrane Fuel Cells. Contamination and mitigation strategies; CRC Press, 2010, pp. 85-114.

[5] Y. Nagahara, S. Sugawara, K. Shinohara, The impact of air contaminants on PEMFC performance, J. Power Sources182 (2008) 422.

[6] D. Imamura, E. Yamaguchi, Effect of air contaminants on electrolyte degradation in PEMFC, ECS Trans. 25 (2009) 813.

[7] F.H. Garzon, F.A. Uribe, Effects of contaminants of catalyst activity, in: W. Vielstich, H.A. Gasteiger, A. Lamm, H. Yokokawa (Eds.), Handbook of Fuel Cells - Fundamentals, Technology and Applications, vol. 5. Advances in electrocatalysis, materials, diagnostics and durability, John Wiley \& Sons, 2010.

[8] B.D. Gould, O.A. Baturina, K.E. Swider-Lyons, Deactivation of Pt/VC PEMFC cathodes by $\mathrm{SO}_{2}$, $\mathrm{H}_{2} \mathrm{~S}$ and COS, J. Power Sources 188 (2009) 89. 
[9] S. Tsushima, K. Kaneko, H. Morioka, S. Harai, Influence of $\mathrm{SO}_{2}$ concentration and relative humidity on electrode poisoning in PEMFC, J. Therm. Sci. Technol. 7 (2012) 619.

[10] X.-Z. Yuan, H. Li, Y. Yu, M. Jiang, W. Qian, S. Zhang, H. Wang, S. Wessel, T.T.H. Cheng, Diagnosis of contamination introduced by ammonia at the cathode in a PEMFC, Int. J. Hydrogen Energy 37 (2012) 12464.

[11] D. Yang, J. Ma, L. Xu, M. Wu, H. Wang, The effect of nitrogen oxides in air on the performance of PEMFC, Electrochim. Acta 51 (2006) 4039.

[12] D. Imamura, K.Ohno, Impact of $\mathrm{Na}^{+}$and $\mathrm{Cl}^{-}$on degradation of PEMFC, LRD25-49, Fuel Cell Seminar 2009, November 16-19, 2009, Palm Springs, CA, USA.

[13] M.S. Mikkola, T. Rockward, F.A. Uribe, B.S. Pivovar, The effect of $\mathrm{NaCl}$ in the cathode air stream on PEMFC performance, Fuel Cells 7 (2007) 153.

[14] O. Baturina, A. Epsteyn, P. Northrup, K. Swider-Lyons, The influence of cell voltage on the performance of a PEM fuel cell in presence of $\mathrm{HCl}$ in Air, J. Electrochem. Soc. 161 (2014) F365.

[15] O.A. Baturina, A. Epsteyn, P. Northrup, K. Swider-Lyons, Insights into PEMFC performance degradation from $\mathrm{HCl}$ in air, J. Electrochem. Soc. 158 (2011) B1198.

[16]K. Matsuoka, S. Sakamoto, K. Nakato, A. Hamada, Y. Itoh, Degradation of polymer electrolyte fuel cells under the existence of anion species, J. Power Sources 179 (2008) 560.

[17] H. Li, H. Wang, W. Qian, S. Zhang, S. Wessel, T.T.H. Cheng, J. Shen, S. Wu, Chloride contamination effects on proton exchange membrane fuel cell performance and stability, J. Power Sources 196 (2011) 6249.

[18] H. Li, J. Zhang, K. Fatih, Z. Wang, Y. Tang, Z. Shi, S. Wu, D. Song, J. Zhang, N. Jia, S. Wessel, R. Abouatallah, N. Joos, PEMFC contamination: Testing and diagnosis of toluene-induced cathode degradation, J. Power Sources 185 (2008) 272.

[19] M.S. El-Deab, F. Kitamura, T. Ohsaka, Poisoning effect of selected hydrocarbon impurities on the catalytic performance of $\mathrm{Pt} / \mathrm{C}$ catalysts towards the oxygen reduction reaction, J. Electrochem. Soc. 160 (2013) F651.

[20] J. St-Pierre, Y. Zhai, M. Angelo, Effect of selected airborne contaminants on PEMFC performance, J. Electrochem. Soc. 161 (2014) F280.

[21] J. St-Pierre, M. Virji, Cell performance distribution in a low-temperature proton exchange membrane fuel cell stack during propene contamination, J. Appl. Electrochem. 46 (2016) 169.

[22] T.V. Reshetenko, J. St-Pierre, Study of acetylene poisoning of Pt cathode on proton exchange membrane fuel cell spatial performance using a segmented cell system, J. Power Sources 287 (2015) 401.

[23] T.V. Reshetenko, J. St-Pierre, Study of acetonitrile poisoning of Pt cathode on proton exchange membrane fuel cell spatial performance using a segmented cell system, J. Power Sources 293 (2015) 929.

[24] S.A. Penkett, J.H. Butler, M.J. Kurylo, C.E. Reeves, J.M. Rodriguez, H. Singh, D. Tooney, R. Weiss, M.O. Andreae, N.J. Blake, R.J. Cicerone, T. Duafala, A. Golombek, M.A.K. Khalil, J.S. Levine, M.J. Molina, S.M. Schauffler, in: D.A. Albritton, R.T. Watson, P.J. Aucamp (Eds) Scientific Assessment of ozone depletion 1994, http://www.esrl.noaa.gov/csd/assessments/ozone/1994/chapters/chapter10.pdf 
[25] J.H. Shorter, C.E. Kolb, P.M. Crill, R.A. Kerwin, R.W. Talbot, M.E. Hines, R.C. Harriss, Rapid degradation of atmospheric methyl bromide in soils, Nature 377 (1995) 717.

[26] J.H. Butler, Better budgets for methyl bromides?, Nature 403 (2000) 260.

[27] S.A. Yvon-Lewis, E.S. Saltzman, S.A. Montzka, Recent trends in atmospheric methyl bromide: analysis of post-Montreal Protocol variability, Atmos. Chem. Phys. 9 (2009) 5963.

[28] Toxicological profile for bromomethane, US Department of health and human services, Public health services, Agency for toxic substances and disease registry, 1992.

[29] W. Mabey, T. Mill, Critical review of hydrolysis of organic compounds in water under environmental conditions, J. Phys. Chem. Ref. Data 7 (1978)383.

[30] S. Elliott, F.S. Rowland, Methyl halide hydrolysis rates in natural waters, J. Atmos. Chem. 20 (1995) 229.

[31] C. French, I. Harrison, Site preferences, energetics and orientation of $\mathrm{CH}_{3} \mathrm{Br}$ on $\mathrm{Pt}$ (111): investigation by RAIRS, TPD and photofragment angular distributions, Surf. Sci. 387 (1997) 11.

[32] S. Wehner, J. Küppers, Interaction of gaseous D atoms with alkyl halides adsorbed on Pt (111), $\mathrm{H} / \mathrm{Pt}$ (111), and C/Pt (111) surfaces: hot-atom and Eley-Rideal reactions. I. Methyl bromide, J. Chem. Phys. 111 (1999) 3209.

[33] T.C. Schwendemann, I. Samanta, T. Kunstalmann, I. Harrison, $\mathrm{CH}_{3} \mathrm{Br}$ structures on Pt (111): Kinetically contolled self-assembly of weakly adsorbed dipolar molecules, J. Phys. Chem. 111 (2007) 1347.

[34] G.N. Salaita, D.A. Stern, F. Lu, H. Baltruschat, B.C. Schardt, J.L. Stickney, M.P. Soriaga, D.G. Frank, A.T. Hubbard, Structure and composition of a platinum (111) surface as a function of $\mathrm{pH}$ and electrode potential in aqueous bromide solution, Langmuir 2 (1986) 828.

[35] B.E. Conway, Y. Phillip, Sh.Y. Qian, Surface electrochemistry and kinetics of anode bromine formation at platinum, J. Chem. Soc. Faraday Trans. 91 (1995) 283.

[36] J.M. Orts, R. Gómez, J.M. Feliu, A. Aldaz, J. Clavilier, Potentiostatic charge displacement by exchanging adsorbed species on Pt (111) electrodes - Acidic electrolytes with specific anion adsorption, Electrochim. Acta 39 (1994) 1519.

[37] R. Gómez, J.M. Feliu, H.D. Abruña, Induced adsorption of chloride and bromide by submonolayer amounts of copper underpotentially deposited on Pt (111), J. Phys. Chem. 98 (1994) 5514.

[38] J.M. Orts, R. Gómez, J.M. Feliu, Bromine monolayer adsorption on Pt (110) surfaces, J. Electroanal. Chem. 467 (1999) 11.

[39] H.A. Gasteiger, N.M. Marković, P.N. Ross, Jr., Bromide adsorption on Pt (111): Adsorption isotherm and electrosorptionvalency deduced from $\mathrm{RRD}_{\mathrm{Pt}(111)} \mathrm{E}$ measurements, Langmuir 12 (1996) 1414.

[40] N.M. Marković, C.A. Lucas, H.A. Gasteiger, P.N. Ross, Bromide adsorption on Pt (100): rotating ring-Pt (100) disk electrode and surface X-ray scattering measurements, Surf. Sci. 365 (1996) 229.

[41] N.M. Marković, H.A. Gasteiger, B.N. Grgur, P.N. Ross, Oxygen reduction reaction on Pt (111): effects of bromide, J. Electroanal. Chem. 467 (1999) 157.

[42] J.X. Wang, N.S. Marinković, R.R. Adžić, Structure of Br adlayers in the course of electrocatalytic reactions $\mathrm{O}_{2}$ reduction on Pt (111) and Au (100), Colloids Surf. A 134 (1998) 165. 
[43] S. Ferro, A. de Battisti, The bromine electrode. Part 1: Adsorption phenomena at polycrystalline platinum electrodes, J. Appl. Electrochem. 34 (2004) 981.

[44] D. Trinh, M. Kedda, X.R. Nóvoa, V. Vivier, Characterization of adsorbates by transient measurements in scanning electrochemical microscopy, Electrochim. Acta 131 (2014) 28.

[45] J. Xu, N.S. Georgescu, D.A. Scherson, The oxidation of bromide on platinum electrodes in aqueous acidic solution: Electrochemical and in situ spectroscopic studies, J. Electrchem. Soc. 161 (2014) H392.

[46] S. Tanaka, S.-L. Yau, K. Itaya, In-situ scanning tunneling microscopy of bromine adlayers on Pt (111), J. Electroanal. Chem. 396 (1995) 125.

[47] L.C. Pérez, L. Brandão, J.M. Sousa, A. Mendes, Segmented polymer electrolyte membrane fuel cells - A review, Renewable and Sustainable Energy Reviews 15 (2011) 169.

[48] S. Cleghorn, C.R. Derouin, M.S. Wilson, S. Gottesfeld, A printed circuit board approach to measuring current distribution in a fuel cell, J. Appl. Electrochem. 28 (1998) 663.

[49] J. Stumper, S.A. Campbell, D.P. Wilkinson, M.C. Johnson, M. Davis, In-situ methods for the determination of current distributions in PEM fuel cells, Electrochim. Acta 43 (1998) 3773.

[50] M. Noponen, T. Mennola, M. Mikkola, T. Hottinen, P. Lund, Measurement of current distribution in a free-breathing PEMFC, J. Power Sources 106 (2002) 304.

[51] Y.-G. Yoon, W.-Y. Lee, T.-H. Yang, G.-G. Park, Ch.-S. Kim, Current distribution in a single cell of PEMFC, J. Power Sources 118 (2003) 193.

[52] F.N. Büchi, A.B. Geiger, R.P. Neto, Dependance of current distribution on water management in PEFC of technical size, J. Power Sources 145 (2005) 62.

[53] I.A. Schneider, S.A. Freunberger, D. Kramer, A. Wokaun, G.G. Scherer, Oscillations in gas channels. Part I. The forgotten player in impedance spectroscopy in PEFCs, J. Electrochem. Soc. 154 (2007) B383.

[54] I.A. Schneider, D. Kramer, A. Wokaun, G.G. Scherer, Oscillations in gas channels. Part II. Unraveling the characteristics of the low frequency loop in air-fed PEFC impedance spectra, J. Electrochem. Soc. 154 (2007) B770.

[55] D.G. Sanchez, P.L. Garcia-Ybarra, PEMFC operation failure under severe dehydration, Int. J. Hydrogen Energy 37 (2012) 7279.

[56] T.V. Reshetenko, G. Bender, K. Bethune, R.Rocheleau, Systematic study of back pressure and anode stoichiometry effects on spatial PEMFC performance distribution, Electrochim. Acta56 (2011) 8700 .

[57] T.V. Reshetenko, G. Bender, K. Bethune, R. Rocheleau, Systematic studies of the gas humidification effects on spatial PEMFC performance distributions, Electrochim. Acta 69 (2012) 220.

[58] T.V. Reshetenko, G. Bender, K. Bethune, R.Rocheleau, Application of a segmented cell setup to detect pinhole and catalyst loading defects in proton exchange membrane fuel cells, Electrochim. Acta 76 (2012) 16.

[59] T.V. Reshetenko, G. Bender, K. Bethune, R.Rocheleau, Effects of local variations of the gas diffusion layer properties on PEMFC performance using a segmented cell system, Electrochim. Acta 80 (2012) 368 . 
[60] T.V. Reshetenko, J. St-Pierre, K.Artyushkova, R.Rocheleau, P.Atanassov, G. Bender, M.Ulsh, Multianalytical study of the PTFE content local variationof the PEMFC gas diffusion layer, J. Electrochem. Soc. 160 (2013) F1305.

[61] M. Schulze, E. Gülzow, St. Schönbauer, T. Knori, R.Reissner, Segmented cell as tool for development of fuel cells and error prevention/prediagnostic in fuel cell stack, J. Power Sources 173 (2007) 19.

[62]R. Lin, E. Gülzow, M. Schulze, K.A. Friedrich, Investigation of membrane pinhole effects in polymer electrolyte fuel cells by locally resolved current density, J. Electrochem. Soc. 158 (2011) B11.

[63] L.C. Pérez, J. Ihonen, J.M. Sousa, A. Mendes, Use of segmented cell operated in $\mathrm{H}_{2}$ recirculation mode to detect water accumulation in PEMFC, Fuel Cells 13 (2013) 203.

[64] D. Spernjak, J. Fairweather. R. Mukundan, T. Rockward, R.L. Borup, Influence of the microporous layer on carbon corrosion in the catalyst layer of a polymer electrolyte membrane fuel cell, J. Power Sources 214 (2012) 386.

[65]A. Lamibrac, G. Maranzana, O. Lottin, J. Mainka, S. Didierjean, A. Thomas, C. Moyne, Experimental characterization of internal currents during the start-up of a PEMFC, J. Power Sources 196 (2011) 9451.

[66] D. Liang, Q. Shen, M. Hou, Z. Shao, B. Yi, Study of the cell reversal process of large area PEMFC under fuel starvation, J. Power Sources 194 (2009) 847.

[67] M. Dou, M. Hou, Q. Shen, H. Zhang, W. Lu, Z. Shao, B. Yi, Behaviors of PEMFC under oxidant starvation, J. Power Sources 196 (2011) 2759.

[68] T.V. Reshetenko, K. Bethune, M.A. Rubio, R. Rocheleau, Study of low concentration CO poisoning of $\mathrm{Pt}$ anode in a proton exchange membrane fuel cell using spatial electrochemical impedance spectroscopy, J. Power Sources 269 (2014) 344.

[69] C. Wieser, A. Helmbold, E. Gülzow, A new technique for two-dimensional current distribution measurements in electrochemical cells, J. Appl. Electrochem. 30 (2000) 803.

[70] G. Bender, M.S. Wilson, T.A. Zawodzinski, Further refinements in the segmented cell approach o diagnosing performance in polymer electrolyte fuel cells, J. Power Sources 123 (2003) 163.

[71] T. Iwasita, in: W. Vielstich, H.A. Gasteiger, A. Lamm, H. Yokokawa (Eds.), Handbook of Fuel Cells - Fundamentals, Technology and Applications, vol. 2. Electrocatalysis, John Wiley \& Sons, 2010.

[72] B.B. Damaskin, O.A. Petrii, V.V. Batrakov (Eds), Adsorption of organic compounds on electrodes, Plemun Press, New York-London, 1971.

[73] S. Gilman, D. Chu, Methanol effects on the $\mathrm{O}_{2}$ reduction reaction, in: W. Vielstich, H.A. Gasteiger, A. Lamm, H. Yokokawa (Eds.), Handbook of Fuel Cells - Fundamentals, Technology and Applications, vol. 2. Electrocatalysis, John Wiley \& Sons, 2010.

[74] T.E. Springer, T.A. Zawodzinski, M.S. Wilson, S. Gottesfeld, Characterization of polymer electrolyte fuel cells using AC impedance spectroscopy, J. Electrochem. Soc. 143 (1996) 587.

[75] R.D. Harington, M. Henderson, Impedance plane display of a reaction with an adsorbed intermediate, J. Electroanal. Chem. 39 (1972) 81.

[76] D.A. Harrington, B.E. Conway, AC impedance of faradaic reactions involving electrosorbed intermediates - I. Kinetic theory, Electrochim. Acta 32 (1987) 1703. 
[77] Chu-Nan Cao, On the impedance plane displays for irreversible electrode reactions based on the stability conditions of the steady-state. I. One state variable besides electrode potential, Electrochim. Acta 35 (1990) 831.

[78] J.-P. Diard, B. Le Gorrec, C. Montella, Calculation, simulation and interpretation of electrochemical impedances. Part 3. Conditions for observation of low frequency inductive diagrams for atwo-step electron transfer reaction with an adsorbed intermediate species, J. Electroanal. Chem. 326 (1992) 13.

[79] P. Córdoba-Torres, M. Keddam, R.P. Nogueira, On the intrinsic electrochemical nature of the inductance in EIS. A Monte Carlo simulation of the two-consecutive-step mechanism: The flat surface 2 D case, Electrochim. Acta 54 (2008) 518.

[80] M. Ciureanu, H. Wang, Electrochemical impedance study of electrode-membrane assemblies in PEM fuel cells. I. Electro-oxidation of $\mathrm{H}_{2}$ and $\mathrm{H}_{2} / \mathrm{CO}$ mixtures on Pt-based gas-diffusion electrodes, J. Electrochem. Soc. 146 (1999) 4031.

[81] N. Wagner, M. Schulze, Change of EIS during CO poisoning of the Pt and PtRu anodes in a membrane fuel cell (PEFC), Electrochim. Acta 48 (2003) 3899.

[82] F. Hajbolouri, B. Andreaus, G.G. Scherer, A. Wokaun, CO tolerance of commercial Pt and PtRu gas diffusion electrodes in polymer electrolyte fuel cells, Fuel Cells 4 (2004) 160.

[83] J.T. Müller, P.M. Urban, W.F. Hölderich, Impedance studies on direct methanol fuel cell anodes, J. Power Sources 84 (1999) 157.

[84] D. Chakraborty, I. Chorkendorff, T. Johannessen, Electrochemical impedance spectroscopy study of methanol oxidation on nanoparticulatePtRu direct methanol fuel cell anodes: Kinetics and performance evaluation, J. Power Sources 162 (2006) 1010.

[85] R.E. Melnick, G.T.R. Palmore, Impedance spectroscopy of the electro-oxidation of methanol on polished polycrystalline platinum, J. Phys. Chem. B 105 (2001) 1012.

[86] V.S. Bagotzky, Yu.B. Vassilyev, J. Weber, J.N. Pirtskhalava, Adsorption of anions on smooth platinum electrodes, J. Electroanal. Chem. 27 (1970) 31.

[87] D.A. Stern, H. Baltruschat, M. Martinez, J.L. Stickney, D. Song, S.K. Lewis, D.G. Frank, A.T. Hubbard, Characterization of single-crystal electrode surfaces as a function of potential and $\mathrm{pH}$ by Auger spectroscopy and LEED. Pt (111) in aqueous $\mathrm{CaCl}_{2}$ and $\mathrm{HCl}$ solutions, J. Electroanal. Chem. 217 (1987) 101.

[88] H. Baltruschat, M. Martinez, S.K. Lewis, F. Lu, D. Song, D.A. Stern, A. Datta, A.T. Hubbard, Structure and composition of the $\operatorname{Pt}(\mathrm{s})[6(111) \mathrm{x}(111)]$ step-terrace surface vs. $\mathrm{pH}$ and potential in aqueous $\mathrm{Br}^{-}$solutions. Studies by LEED and Auger spectroscopy, J. Electroanal. Chem. 217 (1987) 111.

[89] D. Strmcnik, M. Escudero-Escribano, K. Kodama, V.R. Stamenkovic, A. Cuesta, N.M. Marković, Enhanced electrocatalysis of the oxygen reduction reaction based on patterning of platinum surfaces with cyanide, Nature Chem. 2 (2010) 880.

[90] Z. M. Liu, S. Akhter, B. Roop, J. M. White, Surface photochemistry. 4. Quenching of methyl iodide on platinum (111), J. Am. Chem. Soc. 110 (1988) 8708.

[91] Z. M. Liu, S.A. Costello, B. Roop, S.R. Coon, S. Akhter, J. M. White, Surface photochemistry. 6. $\mathrm{CH}_{3} \mathrm{Br}$ on $\mathrm{Pt}$ (111), J. Phys. Chem. 93 (1989) 7681. 
[92] F. Zaera, H. Hoffmann, P.R. Griffiths, Determination of molecular chemisorption geometries using reflection-adsorption infrared spectroscopy: alkyl halides on Pt (111), J. Elec. Spec. Rel. Phen. 54-55 (1990) 705.

[93] M.A. Henderson, G.E. Mitchell, J.M. White, The chemisorption of methyl halides ( $\mathrm{Cl}, \mathrm{Br}$ and I) on Pt (111), Surf. Sci. 184 (1987) L325.

[94] S.A. Costello, B. Roop, Z.-M. Liu, J.M. White, Photochemistry of $\mathrm{CH}_{3} \mathrm{Br}$ adsorbed on Pt (111), J. Phys. Chem. 92 (1988) 1019.

[95] Y. Zhou, W.M. Feng, M.A. Henderson, B. Roop, J.M. White, Surface photochemistry: Products retained on Pt (111) during photolysis of adsorbed $\mathrm{CH}_{3} \mathrm{Br}$, J. Am. Chem. Soc. 110 (1988) 4447.

[96] I.A. Pašti, S.V. Mentus, Halogen adsorption on Pt (111) and palladium monolayer electrocatalysts: DFT study, ECS Trans. 25 (2010) 79.

[97] N. García-Aráez, V. Climent, E. Herrero, J.M. Feliu, On the electrochemical behavior of the Pt (100) vicinal surfaces in bromide solutions, Surf. Sci. 560 (2004) 269.

[98] N. García-Aráez, V. Climent, E. Herrero, J.M. Feliu, J. Lipkowski, Thermodynamic studies of bromide adsorption at the Pt (111) electrode surface perchloric acid solutions: Comparison with other anions, J. Electroanal. Chem. 591 (2006) 149.

[99] R.N. Golberg, L.G. Hepler, Thermochemistry and oxidation potentials of the platinum group metals and their compounds, Chem. Rev. 68 (1968) 229.

[100] S.I. Ginzburg, N.A. Ezerskaya, I.V. Prokofieva, N.V. Fedorenko, V.I. Shlenskaya, N.K. Belskii (Eds.), Analytical chemistry of platinum group metals, Nauka, Moscow, 1972.

[101] C.G. Granqvist, R.A. Burhman, Size distributions for supported metal catalysts. Coalescence growth versus Ostwald ripening, J. Catal. 42 (1976) 477.

[102] C.G. Granqvist, R.A. Burhman, Reply to "Comments on the sintering mechanism of supported metal catalysts", J. Catal. 46 (1977) 238.

[103] V. Komanicky, K.C. Chang, A. Menzel, N.M. Marković, H. You, X. Wang, D. Myers, Stability and dissolution of platinum surfaces in perchloricacid corrosion, passivation, and anodic films, J. Electrochem. Soc. 153 (2006) B446.

[104] P.J. Ferreira, G.J. la O', Y. Shao-Horn, D. Morgan, R. Makharia, S. Kocha, H.A. Gateiger, Instability of $\mathrm{Pt} / \mathrm{C}$ Electrocatalysts in Proton Exchange Membrane Fuel Cells: A Mechanistic Investigation, J. Electrochem. Soc. 152 (2005) A2256.

[105] I.V. Zenyuk, S. Lister, Modeling ion conduction and electrochemical reactions in water films on thin-film metal electrodes with application to low temperature fuel cells, Electrochim. Acta 146 (2014) 194.

[106] O. Antoine, Y. Bultel, R. Durand, Oxygen reduction reaction kinetics and mechanism on platinum nanoparticles inside Nafion, J. Electroanal. Chem. 499 (2001) 85.

[107] S.K. Roy, M.E. Orazem, B. Tribollet, Interpretation of low-frequency inductive loops in PEM fuel cells, J. Electrochem. Soc. 154 (2007) B1378.

[108] A. Dhanda, R. O'Hayre, H. Pitsch, ORR adsorbate dynamics on Pt single crystal PEM fuel cells, ECS Trans. 16 (2008) 1131. 